Pacific Northwest Laboratory Annual Report for 1984 to the Assistant Secretary for Policy Safety and Environment

Part 5 Overview and Assessment

February 1985

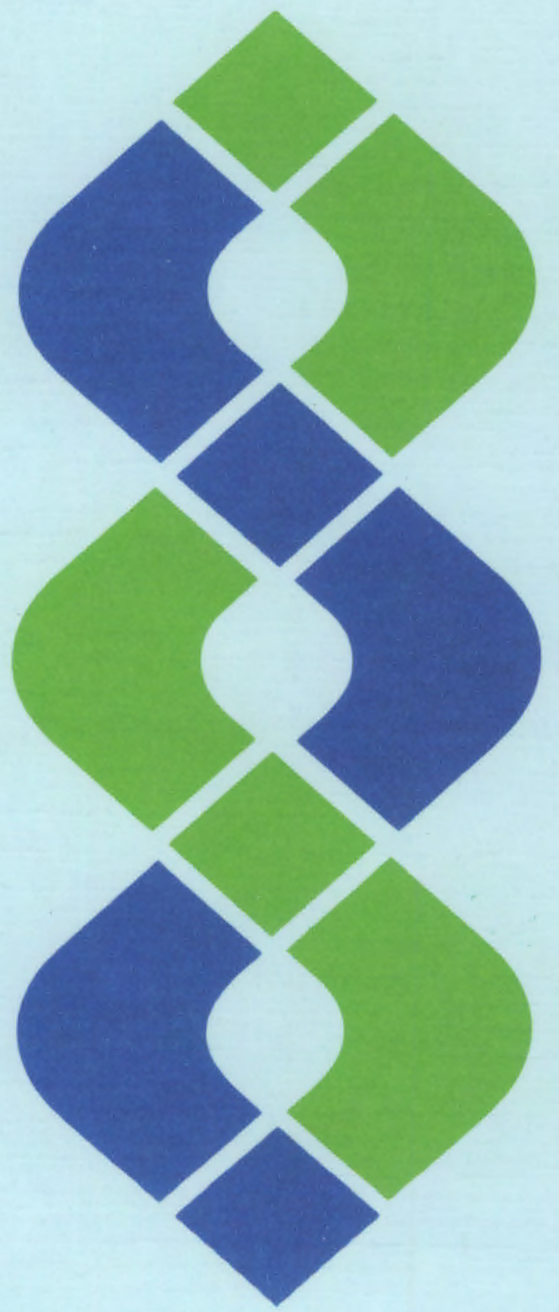

Prepared for the U.S. Department of Energy under Contract DE-AC06-76RLO 1830

Pacific Northwest Laboratory Operated for the U.S. Department of Energy by Battelle Memorial Institute 


\title{
DISCLAIMER
}

This report was prepared as an account of work sponsored by an agency of the United States Government. Neither the United States Government nor any agency thereof, nor any of their employees, makes any warranty, express or implied, or assumes any legal liability or responsibility for the accuracy, completeness, or usefulness of any information, apparatus, product, or process disclosed, or represents that its use would not infringe privately owned rights. Reference herein to any specific commercial product, process, or service by.. trade name, trademark, manufacturer, or otherwise, does not necessarily constitute or imply its endorsement, recommendation, or favoring by the United States Government or any agency thereof. The views and opinions of authors expressed herein do not necessarily state or reflect those of the United States Government or any agency thereof.

\author{
PACIFIC NORTHWEST LABORATORY \\ operated by \\ BATTELLE \\ for the \\ UNITED STATES DEPARTMENT OF ENERGY \\ under Contract DE-AC06-76RLO 1830
}

\begin{tabular}{|c|c|}
\hline \multirow{2}{*}{\multicolumn{2}{|c|}{ Printed in the United States of America }} \\
\hline & \\
\hline \multicolumn{2}{|c|}{$\begin{array}{l}\text { Available from } \\
\text { National Technical Information Service }\end{array}$} \\
\hline \multicolumn{2}{|c|}{ United States Department of Commerce } \\
\hline \multirow{2}{*}{\multicolumn{2}{|c|}{$\begin{array}{c}5285 \text { Port Royal Road } \\
\text { Springfield, Virginia } 22161\end{array}$}} \\
\hline & \\
\hline \multirow{2}{*}{\multicolumn{2}{|c|}{$\begin{array}{l}\text { NTIS Price Codes } \\
\text { Microfiche A01 }\end{array}$}} \\
\hline & \\
\hline \multicolumn{2}{|c|}{ Printed Copy } \\
\hline & Price \\
\hline Pages & Codes \\
\hline $001-025$ & A02 \\
\hline 026-050 & A03 \\
\hline $051-075$ & $A 04$ \\
\hline 076-100 & A05 \\
\hline $101-125$ & A06 \\
\hline $126-150$ & A 07 \\
\hline $151-175$ & $A 08$ \\
\hline $176-200$ & $A 09$ \\
\hline $201-225$ & A010 \\
\hline $226-250$ & A011 \\
\hline $251-275$ & A012 \\
\hline $276-300$ & $A 013$ \\
\hline
\end{tabular}




\section{Pacific Northwest Laboratory \\ Annual Report for 1984 to the DOE Office of the Assistant Secretary for Policy, Safety, and Environment}

\section{Part 5 Overview and Assessment}

W. J. Bair and Staff Members

of Pacific Northwest Laboratory

February 1985

Prepared for the U.S. Department of Energy under Contract DE-AC06-76RLO 1830

Pacific Northwest Laboratory

Richland, Washington 99352 



\section{PREFACE}

This 1984 annual report from Pacific Northwest Laboratory (PNL) to the Department of Energy (DOE) describes research in environment, health, and safety conducted during fiscal year 1984. The report again consists of five parts, each in a separate volume.

The five parts of the report are oriented to particular segments of our program. Parts 1 to 4 report on research performed for the DOE Office of Health and Environmental Research in the Office of Energy Research. Part 5 reports progress on all research performed for the Assistant Secretary for Policy, Safety, and Environment. In some instances, the volumes report on research funded by other DOE components or by other governmental entities under interagency agreements. Each part consists of project reports authored by scientists from several PNL research departments, reflecting the multidisciplinary nature of the research effort.

The parts of the 1984 Annual Report are:

Part 1: Biomedical Sciences

Program Manager - J. F. Park

Part 2: Environmental Sciences

Program Manager - B. E. Vaughan

Part 3: Atmospheric Sciences

Program Manager - C. E. Elderkin
D. L. Felton, Report Coordinator and Editor

B. E. Vaughan, Report Coordinator C. M. Novich, Editor

N. S. Laulainen, Report Coordinator

E. L. Owczarski, Editor

R. M. Garcia, Report Coordinator

J. E. Danko, Editor

Part 5: Overview and Assessment

Program Manager - W. A. Glass

R. W. Baalman, Report Coordinator and Editor

Activities of the scientists whose work is described in this annual report are broader in scope than the articles indicate. PNL staff have responded to numerous requests from DOE during the year for planning, for service on various task groups, and for special assistance. 
Credit for this annual report goes to many scientists who performed the research and wrote the individual project reports, to the program managers who directed the research and coordinated the technical progresss reports, to the editors who edited the individual project reports and assembled the five parts, and to Ray Baalman, editor in chief, who directed the total effort.

W. J. Bair, Manager

S. Marks, Associate Manager

Environment, Health and Safety

Research Program

Previous reports in this series:

\section{Annual Report for}

$\begin{array}{ll}1951 & \text { W-25021, HW-25709 } \\ 1952 & \text { HW-27814, HW-28636 } \\ 1953 & \text { HW-30437, HW-30464 } \\ 1954 & \text { HW-30306, HW-33128, HW-35905, HW-35917 } \\ 1955 & \text { HW-39558, HW-41315, HW-41500 } \\ 1956 & \text { HW-47500 } \\ 1957 & \text { HW-53500 } \\ 1958 & \text { HW-59500 } \\ 1959 & \text { HW-63824, HW-65500 } \\ 1960 & \text { HW-69500, HW-70050 } \\ 1961 & \text { HW-72500, HW-73337 } \\ 1962 & \text { HW-76000, HW-77609 } \\ 1963 & \text { HW-80500, HW-81746 } \\ 1964 & \text { BNWL-122 } \\ 1965 & \text { BNWL-280; BNWL-235, Vol, 1-4; BNWL-361 } \\ 1966 & \text { BNWL-480, Vol. 1; BNWL-481, Vol. 2, Pt. 1-4 } \\ 1967 & \text { BNWL-714, Vol. 1; BNWL-715, Vol. 2, Pt. 1-4 } \\ 1968 & \text { BNWL-1050, Vol. 1, Pt. 1-2; BNWL-1051, Vol. 2, Pt. 1-3 } \\ 1969 & \text { BNWL-1306, Vol. 1, Pt. 1-2; BNWL-1307, Vol. 2, Pt. 1-3 } \\ 1970 & \text { BNWL-1550, Vol. 1, Pt. 1-2; BNWL-1551, Vol. 2, Pt. 1-2 } \\ 1971 & \text { BNWL-1650, Vol. 1, Pt. 1-2; BNWL-1651, Vol. 2, Pt. 1-2 } \\ 1972 & \text { BNWL-1750, Vol. 1, Pt. 1-2; BNWL-1751, Vol. 2, Pt. 1-2 } \\ 1973 & \text { BNWL-1850, Pt. 1-4 } \\ 1974 & \text { BNWL-1950, Pt. 1-4 } \\ 1975 & \text { BNWL-2000, Pt. 1-4 } \\ 1976 & \text { BNWL-2100, Pt. 1-5 } \\ 1977 & \text { PNL-2500, Pt. 1-5 } \\ 1978 & \text { PNL-2850, Pt. 1-5 } \\ 1979 & \text { PNL-3300, Pt. 1-5 } \\ 1980 & \text { PNL-3700, Pt. 1-5 } \\ 1981 & \text { PNL-4100, Pt. 1-5 } \\ 1982 & \text { PNL-4600, Pt. 1-5 } \\ 1983 & \text { PNL-5000, Pt. 1-5 } \\ & \\ 1961 & \\ 1961 & \end{array}$




\section{FOREWORD}

Part 5 of the 1984 Annual Report to the Department of Energy's Assistant Secretary for Environmental Protection, Safety and Emergency Preparedness presents Pacific Northwest Laboratory's progress on work performed for the Office of Nuclear Safety, the Office of Operational Safety, and for the Office of Environmental Analysis. For each project, as identified by the Field Task Proposal/Agreement, articles describe progress made during FY 1984. Authors of these articles represent a broad spectrum of capabilities derived from various segments of the Laboratory, reflecting the interdisciplinary nature of the work.

For additional information on any of the projects reported in Part 5, contact the authors of the articles. 



\section{CONTENTS}

PREFACE $\ldots \ldots \ldots \ldots \ldots \ldots \ldots \ldots \ldots \ldots \ldots \ldots \ldots \ldots \ldots \ldots \ldots \ldots \ldots \ldots \ldots \ldots \ldots \ldots$

FOREWORD $\ldots \ldots \ldots \ldots \ldots \ldots \ldots \ldots \ldots \ldots \ldots \ldots \ldots \ldots \ldots \ldots \ldots \ldots \ldots \ldots \ldots, \ldots$

\section{ENVIRONMENTAL ANALYSIS}

Uncertainties in Modeling Source/Receptor Relations for Acidic Deposition Modeling Source/Receptor Relations-Acid Deposition, C. Berkowitz ...........

\section{NUCLEAR SAFETY}

Health Physics Support and Assistance to the Department of Energy

Technical Evaluation of the Capability of Present Instrumentation to Meet the Draft ANSI Standard (N42.17) on Performance Specifications for Radiation Protection Survey Instrumentation, f. L. Kenoyer, K. L. Swinth ................ 7 Technical Evaluation of Draft ANSI Standard N13.30 Performance Criteria for Radiobioassay, D. R. Fisher, A. V. Robinson, R. T. Hadley . . . . . . . . . . . 8 Characterization of DOE Facility Emergency Preparedness, K.L. Swinth, 1. A. Maclellan, J. M. Pisarcik, A. V. Robinson, B. L. Murphy, J. M. Selby ......... 10 DOE Program for Improving Air Sampling and Monitoring, I. L. Kenoyer,

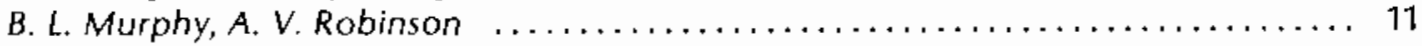
DOE ALARA (As Low As Reasonably Achievable) Upgrade, L. H. Munson,

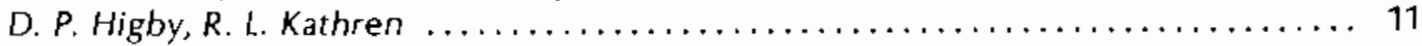
Evaluation and Upgrade of DOE Internal Dosimetry Practices, B. L. Murphy, K. R. Heid, R. J. Traub, A. V. Robinson $\ldots \ldots \ldots \ldots \ldots \ldots \ldots \ldots \ldots \ldots \ldots \ldots \ldots \ldots \ldots 11$ Standards Evaluation, 1. M. Selby, B. L. Murphy, K. R. Heid, J. P. Corley ......... 12 Health Physics Technician Training Characterization for DOE Contractors,

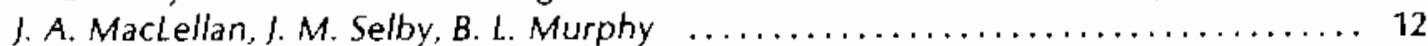
Radiation Records Systems at DOE Facilities, R. J. Traub, B. L. Murphy . . . . . . . ... 13 Extremity Dose Measurements Evaluation and Upgrading, B. L. Murphy,

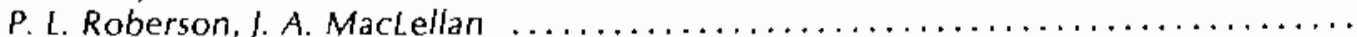

Technical Guidelines for Radiological Calibrations

Technical Guidelines for Radiological Calibrations, J. C. McDonald, P. L. Roberson, K. L. Swinth

Personnel Neutron Dosimeter Evaluation and Upgrade Program Personnel Neutron Dosimeter Evaluation and Upgrade Program, L. G. Faust, D. E. Hadlock, L. W. Brackenbush, M. A. Parkhurst, I. C. McDonald, R. I. Scherpelz,

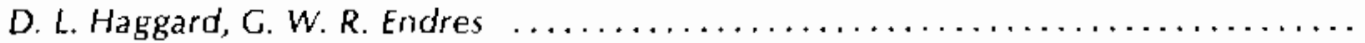

Beta Measurement Evaluation and Upgrade

Beta Measurement Evaluation and Upgrade, K. L. Swinth, L. A. Rathbun,

P. L. Roberson, G. W. R. Endres

\section{Department of Energy Laboratory Accreditation Program for Occupational Exposure Measurements}

Department of Energy Laboratory Accreditation Program for Occupational

Exposure Measurements, P. L. Roberson, R. A. Fox, C. D. Hooker, B. L. Murphy .... 


\section{OPERATIONAL SAFETY}

\section{Assurance Program for Remedial Action}

Technical Assistance to DOE/OOS Assurance Program for Remedial Action

(APRA), D. H. Denham; F. I. Cross; W. E. Kennedy, Ir.; S. Marks; /. K. Soldat;

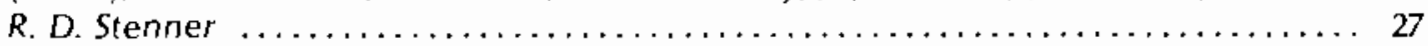

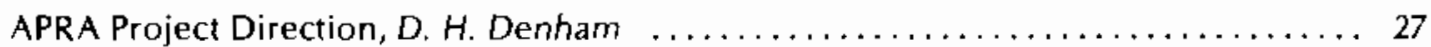

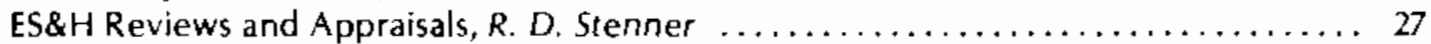

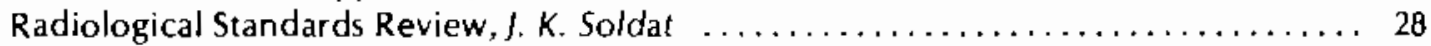

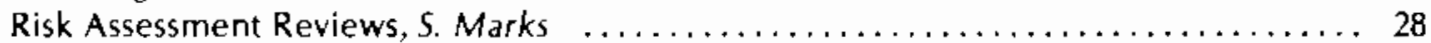

\section{Environmental Protection Support and Assistance}

Environmental Protection Support and Assistance to DOE/OOS, W. E. Kennedy, /r.;

R. E. Jaquish; I. P. Corley; R. C. Adams; K. A. Hawley; K. L. Imhoff; R. R. Kinnison;

E. B. Moore, Jr; I. R. Raymond; J. K. Soldat; E. C. Watson .................... 29

Effluent and Environmental Monitoring Guides, J. P. Corley, J. K. Soldat,

E. C. Watson ............................................... 29

Quality Assurance for DOE Environmental and Effluent Monitoring, R. E. Jaquish,

R. R. Kinnison ............................................ 29

Environmental Dose Assessment Methodology, /. P. Corley .................. 29

Annual Environmental Summary Report, $K$. A. Hawley $\ldots \ldots \ldots \ldots \ldots \ldots \ldots \ldots \ldots \ldots$

Environmental Data Reporting, E. B. Moore, Ir. .......................... 30

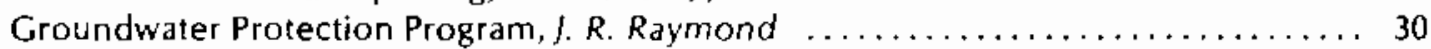

Fifth DOE Environmental Protection Information Meeting, I. P. Corley;

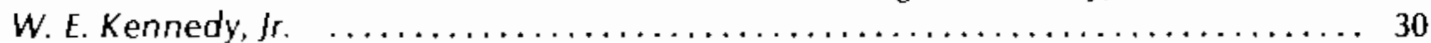

Risk Value Methodology Development, $R$. C. Adams, K. L. Imhoff ............. 30

Special Assistance, W. E. Kennedy, /r.; J. P. Corley ....................... 30

\section{Hazardous Waste Risk Assessment}

Groundwater Monitoring Workshop, B. L. Steelman, R. Schalla, I. M. Meuser,

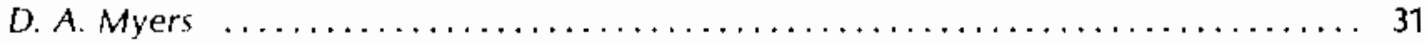

Review of DOE Field Office Groundwater Monitoring Plans, B. L. Steelman,

D. A. Myers, G. L. Mckown, P. VanVoris, S. R. Peterson ..................... 31

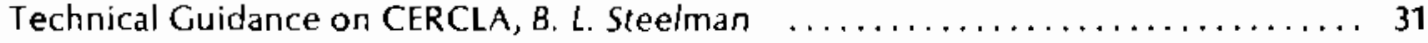

Modification of the EPA Hazard Ranking System, B. A. Napier, K. A. Hawley ........ 31

Methodology for Establishing Priority of Inactive Waste Sites, G. Whelan,

B. L. Steelman, ). V. Ramsdell, D. L. Strenge, B. A. Napier .................... 31

Organics Contamination of Groundwater, R. M. Ecker, B. L. Steelman $\ldots \ldots \ldots \ldots \ldots, 32$

Policy Studies-Radiation

Policy Analysis, W. J. Bair ..................................... 33

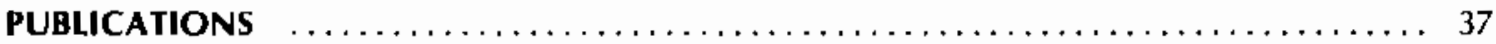

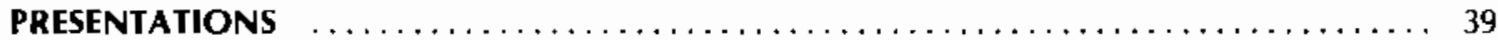

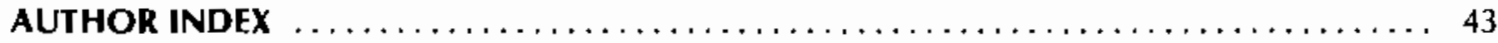

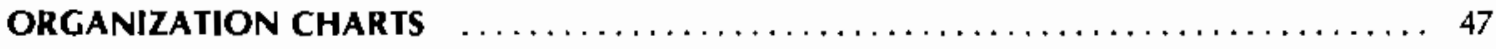

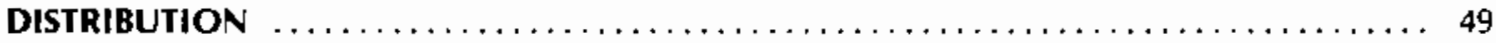


Environmental Analysis 


\section{ENVIRONMENTAL ANALYSIS}

- Uncertainties in Modeling Source/Receptor Relations for Acidic Deposition

The Office of Environmental Analysis represents the Department of Energy's interests in the Federal regulatory development processs, maintains comprehensive environmental data bases, conducts anticipatory analyses for early identification and scoping of emerging regulatory issues, and provides environmental technical support and guidance to Departmental programs. 



\section{- Uncertainties in Modeling Source/Receptor Relations for Acidic Deposition}

Contributions of various processes related to modeling source/receptor relations in long-range transport were examined. Initial results are presented.

MODELING SOURCE/RECEPTOR RELATIONS--ACID DEPOSITION

c. Berkowitz

The purpose of this study is to quantify uncertainty in model/observation relations in the areas of (1) atmospheric chenistry, (2) trajectories based on single and multiple layer methods, and (3) interannual variability in meteorology. Extensive use has been made of residual analysis (Daniel and wood 1980), examination of frequency diagrams, and response surface functions (Draper and Smith 1981). The Regional Air Pollutant Transport Model (McNaughton, Powe11, and Berkowitz 1981), a multi-layer version of RAPT, and a statistical model (Shein 1977) are the basic tools of this study.

A set of experiments in which input parameters to RAPT were varied by a hypercube sampling method demonstrated that the deposition velocity of $\mathrm{SO}_{2}$ strongly governs the root mean square fit between model predictions and the corresponding observations. Such a result is not surprising; this deposition velocity effectively reduces or increases the resulting emission field in a model with linear chemistry (such as RAPT has).
In another set of experiments, assorted measures of "goodness of fit" were calculated as functions of different areas over which the observations and predictions were combined. It was found that there is a significant improvement in model performance for areas greater than $14 \times 10^{5} \mathrm{~km}^{2}$; below this area, the model performs significantly worse.

\section{References}

Daniel, C and F. S. Wood. 1980 Fitting Equations to Data. Wiley and Sons. 2nd Ed.

Draper, N. and H. Smith. 1981. Applied Regression Analysis. Wiley and Sons.

McNaughton, D. J., D. C. Powell and C. M. Berkowitz. 1981. RAPT-The Pacific Northwest Laboratory Regional Air Pollutant Transport Model. PNL-3390. Prepared for U.S. EPA under a Related Services Agreement with DOE.

Sheih, C. M. 1977 Application of a Statistical Trajectory Model to the Simulation of Sulfur Pollution Over Northeastern United States. Atmospheric Environment Vol II, pp. $173-178$. 

Nuclear Safety 


\section{NUCLEAR SAFETY}

- Health Physics Support and Assistance to the Department of Energy

- Technical Guidelines for Personnel Dosimetry Calibrations

- Personnel Neutron Dosimeter Evaluation and Upgrade

- Beta Measurement Evaluation and Upgrade

- DOE Laboratory Accreditation Program for Occupational Exposure Measurements

To establish and maintain an effective nuclear safety program, DOE has assigned to the Office of Nuclear Safety responsibility for developing and promulgating nuclear safety policy, standards, and guidance and for DOE-wide independent overview, support, and counsel. The objective of the Nuclear Safety Program is to assure that the activities of the Department of Energy (DOE) and its contractors are in full compliance with DOE and other applicable nuclear safety, health, and emergency preparedness standards and regulations and to provide technical support to the DOE Office of Nuclear Safety.

The major emphasis at Pacific Northwest Laboratory continues to be on developing criteria, instruments, and methods to assure that radiation exposure to occupational personnel and to people in the environs of nuclear facilities is maintained as low as reasonably achievable. Particular emphasis has been placed on improving basic personnel exposure measurement and recording programs and on improving reporting systems

- Bullets denote Field Task Proposa!/Agreement (FTPA) titles. 



\section{- Health Physics Support and Assistance to the Department of Energy}

Pacific Northwest Laboratory functions as the lead laboratory providing health physics support and assistance to the DOE Division of Operational Safety on special studies principally associated with the analysis of impact of standards, regulations, and engineering and administrative actions on occupational and environmental exposure. Support and assistance are also provided for other specific tasks or special studies identified by DOE as priorities. The designation of lead laboratory in health physics, with an agreement and budget in place, provides the Division with the additional expertise necessary to respond to the many questions and situations that arise during the operation of their numerous nuclear energy research, development, and demonstration facilities.

TECHNICAL EVALUATION OF THE CAPABILITY OF PRESENT INSTRUMENTATION TO MEET THE ORAFT ANSI STANDARD (N42.17) ON PERFORMANCE SPECIFICATIONS FOR RAOIATION PROTECTION SURVEY IMISTRUMENTATION*

\section{J. L. Kenoyer, K. L. Swinth}

This study was established to evaluate the applicability and practicality of the proposed American National Standards Institute (ANSI) Standard "Performance Specifications for Radiation Protection Survey Instrumentation (N42.17);" to determine the degree of confomance to the proposed standard of selected currently available commercial instruments; to develop a formal test and evaluation protocol and specific procedures; and to lay the ground work for establishing a permanent testing laboratory.

During the past year, a total of ninety-rine portable health physics instruments were evalwated with the testing procedures based on the requirements in ANSI N42.1703. These included forty Geiger-Mueller (GM) detectors, twenty-one ion chambers (IC), twenty-seven alpha survey meters, nine neutron monitors, and two scintillation-type low-level gantra survey meters.

These instruments have been procured through three methods: purchase directly from the manufacturers, loan from instrument manufacturers, and loan from Department of Energy (DOE) laboratories and Nuclear Regulatory Commission (NRC) licensees. Instruments have been borrowed from nine commercial vendors as well as six DOE laboratories and one nuclear power station.

Modifications were made in several of the testing procedures in order to incorporate changes in the draft standard that were made

\#This task is jointiy sponsored by the Department of Energy and the Nuclear Regulatory Commission. during a January meeting of the ANSI warking group. These procedures were then reverified before being implemented in the testing program.

Data have been obtained with the following testing procedures for "normal" environments: inspection, battery lifetime, stability, geotropism, response time, accuracy, precision, IER energy dependence, beta energy dependence, angular dependence, temperature, humidity, ambient pressure, AC power, radiation overloads, nonionizing electromagnetic radiations, electrostatic fields, extracameral response, magnetic fields, interfering ionizing radiations, alarm threshold drift, alarm reset, vibration shock, and temperature shock. Selected results from these tests are listed in Table I for GM detectors, IC, alpha survey meters, and neutron dose equivalent survey instruments. During the last year, over 250 tests were performed with these instruments.

Data have also been obtoined with procedures for use under extreme environmental conditions, including temperature shock, condensing atmosphere, and exposure to high-energy photons. A limited number of instruments have been tested with the extreme range temperature shock procedure. Results for the condensing atmosphere test are 1 isted in Table 1. All of the instruments exposed to high-energy photons from ${ }^{16} \mathrm{~N}$ (i.e., 6.12 and $7.11 \mathrm{MeV}$ photons) overresponded when compared to the response to ${ }^{137} \mathrm{Cs}$ (i.e., $0.66 \mathrm{MeV}$ photons). The ratio of the response to $16 \mathrm{~N}$ radiations to the response to ${ }^{137} \mathrm{Cs}$ radiations after normalization to the conventionally true values of each source ranged from 1.1 to 3.9. For five ICS, this overresponse ratio ranged from 1.1 to 2.2 . For eighteen GM detectors, the ratio ranged from 1.4 to 3.9; five of these instruments overresponded by factors of 1.4 to 2.0 , ten instruments overresponded by factors of 2.1 to 2.9 , and the three remaining instruments overresponded by factors of 3.3 to 3.9 . 
TABLE 1. Selected Testing Results

Test

AC power

Battery lifetime

Alarm resei

Alarm threshold drift

Stability

Geotropism

Response time

Precision

Accuracy

IER energy dependence

Radiation overloads

Angular dependence

Temperature

Temperature shock

Humidity

Ambient pressure

Magnetic fields

RF fields

Electrostatic fields

Extracameral

Vibration

Shuck

Condensing atmosphere

Microwave fields

No. of Failures/No. Tested

\begin{tabular}{|c|c|c|c|}
\hline $\begin{array}{c}\text { lon } \\
\text { hamber }\end{array}$ & $\begin{array}{c}\text { GM } \\
\text { Detector }\end{array}$ & $\begin{array}{c}\text { Alpha } \\
\text { Detector }\end{array}$ & Neutron \\
\hline NT & $0 / 4$ & NT & NA \\
\hline $1 / 5$ & $7 / 19$ & $1 / 5$ & NT \\
\hline NT & $1 / 3$ & NT & NA \\
\hline NT & $0 / 3$ & $N T$ & NA \\
\hline $1 / 9$ & $3 / 35$ & $6 / 15$ & $3 / 4$ \\
\hline $3 / 9$ & $4 / 20$ & $9 / 14$ & $N T$ \\
\hline $8 / 13$ & $13 / 22$ & $0 / 7$ & $3 / 3$ \\
\hline $0 / 15$ & $18 / 23$ & $7 / 8$ & $0 / 3$ \\
\hline $7 / 4$ & $6 / 12$ & NT & NT \\
\hline $4 / 14$ & $18 / 23$ & $\mathrm{NA}$ & $N A$ \\
\hline LNT & $1 / 4$ & $N T$ & NT \\
\hline $8 / 9$ & $19 / 20$ & $N A$ & $0 / 2$ \\
\hline $9 / 17$ & $0 / 22$ & $70 / 13$ & $0 / 3$ \\
\hline $1 / 3$ & $0 / 2$ & $3 / 5$ & $3 / 5$ \\
\hline $1 / 7$ & $4 / 18$ & $10 / 15$ & $0 / 6$ \\
\hline $0 / 7$ & $0 / 5$ & $12 / 13$ & $1 / 6$ \\
\hline $0 / 6$ & $0 / 13$ & NT & NT \\
\hline $2 / 7$ & $2 / 11$ & $0 / 5$ & $0 / 5$ \\
\hline $0 / 7$ & $0 / 13$ & NT & NT \\
\hline$N A$ & $0 / 12$ & $N A$ & NT \\
\hline $1 / 4$ & $1 / 7$ & $0 / 7$ & NT \\
\hline $0 / 3$ & $0 / 8$ & $0 / 7$ & NT \\
\hline $1 / 7$ & $0 / 5$ & $4 / 7$ & $0 / 3$ \\
\hline $4 / 5$ & $3 / 7$ & $2 / 3$ & NT \\
\hline
\end{tabular}

NT - None tested

NA. Not applicable

LNT - Limited number tested

The following conclusions on instrument performance can be made from the results of the testing program:

- A large variability in performance is observed among instruments of the same type from different manufacturers.

- Variability in perfomance is observed between same manufacturer/same model instruments.

- Performance data supplied by many manufacturers are incomplete, unsatisfactory, and at times inaccurate.

- Temperature dependence can be quite severe for ion chambers.

- Host GM instruments currently available are highly IER energy dependent.

- High humidity can affect instrument performance; IC and GM instruments tend to recover when returned to low humidity.

- Air proportional alpha-detection instruments are very sensitive to humidity and pressure changes.
- The rate of pressure drop affects the response of scintillation detectors.

TECHNICAL EVALUATION OF DRAFT ANSI STANDARD M13.30 PERFORMANCE CRITERIA FOR RADIOBIOASSA:*

D. R. Fisher, A. V. Robinson, R. T. Hadley

The purpose of this study is to evaluate the adequacy of draft ANS1 Standard 13.30 performance criteria by conducting a nationwide bioassay intercomparison test. The study involves two rounds of performance testing of iaboratories making in in-vitro (excreta analysis) or in-vivo (external counting? measurements. The performance of bioassay laboratories is judged against criteria specified in the draft Standard for bias, precision, and minimum detectable activity.

During the past year, the first round of invivo testing was completed, and the second round was begun. In addition, the second round of in-vitro testing was completed with

This study is jointly sponsored by the Department of Energy and the Nuclear Regulatory Commission. 
the exception of final data analysis. A large number of laboratories voluntarily par-

ticipated in these tests, including comercial testing laboratories, DOE/DOE-contractor labratories, universities and medical institutions, and commercial nuclear power facilities.

In-vivo testing involved the measurement of radioactivity in the lungs of a torso phanton, in the thyroid of a neck phantom, and in the composite mass of a whole-body bottle phantom. Three interchangeable polyurethane lung sets, each tagged with a different nuclide $\left(235 \mathrm{U}, 241 \mathrm{Am}\right.$, or $\left.{ }^{60} \mathrm{Co}\right)$, were employed. A point source of enriched $40 \mathrm{~K}$ was imbedded into the heart cavity of the torso phantom to provide a ratural $40 \mathrm{~K}$ background interference.

To test whole-body measurement capabilities, a bottle phantom, filled with a gelatinous matrix containing precisely known quantities of ${ }^{137} \mathrm{Cs},{ }^{144} \mathrm{Ce}$, and ${ }^{60} \mathrm{Co}$ along with the background interference radionuclides of $90 \mathrm{Sr}$ and $40 \mathrm{~K}$, was used. Thyroid counting capabilities were tested using capsules containing $131 \mathrm{I}$. All radioactive source materials were provided by the National Bureau of Standards. Invivo laboratories were tested for Minimum Significant Photon Activity (MSPA), bias and precision for several radionuciides. A summary of round one in-vivo test results is given in Table 1. In general, in-vivo counting facilities had bias and precision difficulties measuring whole-body distributions of $1{ }^{44} \mathrm{Ce}$ in the presence of $60 \mathrm{Co}$ and ${ }^{137} \mathrm{Cs}$. A high bias failure rate was also observed for $60 \mathrm{CO}$ in the lung and whole body.
In-vitro measurement capability testing involved preparation of approximately 560 carefully spiked artificial urine samples for round one and 1300 samples for round two. The round two samples, containing known amounts of $241 \mathrm{Am}+238 \mathrm{Pu},{ }^{69} \mathrm{Sr}+{ }^{90} \mathrm{Sr},{ }^{3} \mathrm{H},{ }^{60} \mathrm{Co}+{ }^{137} \mathrm{Cs}$, or natural uranium, were shipped to participating bioassay laboratories for analysis. A third-party cross-check laboratory verified that the intended activity levels were present in the test samples. A preliminary sumary of round two in-vitro test results is given in Table 2.

For in-vitro laboratories, failures in gansa spectrometry, alpha spectrometry, and uranium determinations were observed due to unacceptable minimum detectable activities (MDAs) and bias. Failures in beta measurements for ${ }^{8}{ }^{9} \mathrm{Sr}$ were due to difficulties in meeting bias and precision criteria. These results were comparable to those observed in round one testing.

The intercomparison test results show that both in-vivo and in-vitro laboratories had difficulties meeting the draft Standard performance criteria in several categories. The causes of test failures varied markedly. The test results indicate a need for laboratory accreditation to ensure accurate bioassay results. The present testing program provides an opportunity for laboratories to assess their performance in light of industry standards and to identify areas of weakness; it also reinforces the need for continual quality assurance.

TABLE 1. Summary of Round One In-Vivo Test Results

\begin{tabular}{|c|c|c|c|c|c|c|c|}
\hline \multirow[b]{2}{*}{ Category } & \multirow[b]{2}{*}{ Nuclide } & \multirow[b]{2}{*}{$\begin{array}{l}\text { Number of } \\
\text { Participants }\end{array}$} & \multirow[b]{2}{*}{$\begin{array}{c}\text { Responding } \\
\text { Facilities } \\
\end{array}$} & \multicolumn{4}{|c|}{ Percent Failure } \\
\hline & & & & MSPA & Bias & Precision & $\begin{array}{l}\text { MSPA, } \\
\text { Bias, or } \\
\text { Precision }\end{array}$ \\
\hline Lung & ${ }^{241} \mathrm{Am}$ & 6 & 4 & 0 & 0 & 0 & 0 \\
\hline Lung & $235 \mathrm{U}$ & 7 & 5 & 20 & 20 & 0 & 40 \\
\hline Lung & ${ }^{60} \mathrm{Co}$ & 15 & 13 & 0 & 62 & 0 & 62 \\
\hline Whole body & ${ }^{60} \mathrm{CO}$ & 16 & 14 & 29 & 36 & 7 & 57 \\
\hline Whole body & ${ }^{137} \mathrm{Cs}$ & 15 & 13 & 46 & 15 & 0 & 62 \\
\hline Whole body & ${ }^{144} \mathrm{Ce}$ & 14 & 12 & 58 & 58 & 50 & 92 \\
\hline Thyroid & $131 \mid$ & 28 & 25 & 24 & 20 & 0 & 36 \\
\hline
\end{tabular}


IABLE 2. Preliminary Summary of Round Two In-Vitro Test Results

\begin{tabular}{|c|c|c|c|c|c|c|c|}
\hline \multirow[b]{2}{*}{ Category } & \multirow[b]{2}{*}{ Nuclide } & \multirow[b]{2}{*}{$\begin{array}{l}\text { Number of } \\
\text { Participants }\end{array}$} & \multirow[b]{2}{*}{$\begin{array}{c}\text { Responding } \\
\text { Facilities } \\
\end{array}$} & \multicolumn{4}{|c|}{ Percent Failure } \\
\hline & & & & AMDA & Bias & Precision & $\begin{array}{l}\text { AMDA, } \\
\text { Bias, or } \\
\text { Precision }\end{array}$ \\
\hline $\begin{array}{l}\text { Liquid } \\
\text { scintillation }\end{array}$ & ${ }^{3} \mathrm{H}$ & 35 & 27 & 7 & 26 & 11 & 33 \\
\hline $\begin{array}{l}\text { Camma } \\
\text { spectrometry }\end{array}$ & $\begin{array}{l}{ }^{1+7} \mathrm{Cs} \\
{ }^{60} \mathrm{Co}\end{array}$ & $\begin{array}{l}27 \\
17\end{array}$ & $\begin{array}{l}19 \\
11\end{array}$ & $\begin{array}{l}53 \\
50\end{array}$ & $\begin{array}{l}21 \\
33\end{array}$ & $\begin{array}{r}5 \\
17\end{array}$ & $\begin{array}{l}58 \\
61\end{array}$ \\
\hline $\begin{array}{l}\text { Beta } \\
\text { measurements }\end{array}$ & $\begin{array}{l}595 r \\
905 r\end{array}$ & $\begin{array}{l}17 \\
16\end{array}$ & $\begin{array}{l}6 \\
8\end{array}$ & $\begin{array}{l}17 \\
11\end{array}$ & $\begin{array}{l}50 \\
11\end{array}$ & $\begin{array}{r}33 \\
0\end{array}$ & $\begin{array}{l}67 \\
22\end{array}$ \\
\hline $\begin{array}{l}\text { Alpha } \\
\text { spectrometry }\end{array}$ & $\begin{array}{l}{ }_{21}^{21} \mathrm{Am} \\
{ }_{234} \mathrm{Pu}\end{array}$ & $\begin{array}{l}16 \\
16\end{array}$ & $\begin{array}{l}4 \\
6\end{array}$ & $\begin{array}{l}50 \\
67\end{array}$ & $\begin{array}{r}75 \\
0\end{array}$ & $\begin{array}{l}0 \\
0\end{array}$ & $\begin{array}{l}75 \\
67\end{array}$ \\
\hline $\begin{array}{l}\text { Fluorescence } \\
\text { measurements }\end{array}$ & L'-nat & 20 & 13 & 38 & 46 & 0 & 62 \\
\hline
\end{tabular}

(a) As of September 29, 1984

\section{CHARACTERIZATION OF DOE FACILITY EMERGENCY PREPAREDNESS}

K. L. Swinth, J. A. Maclellan, J. M. Pisarcik, A. V. Robinson, B. L. Murphy, J. M. Selby

The purpose of the energency preparedness task is to update and expand on the emergency instrument performance criteria published in the 19705 and to provide guidance on the proper elements of emergency instrument programs.

The work will entail development of a generic document on emergency preparedness instrumentation followed by documents on emergency instrument performance criteria and requirements for specific categories of facilities.

In 1980, following the Three Mile Island incident, DOE requested Pacific Northwest Laboratory (PNL) to expand and update an earlier study on emergency instrumentation preparedmess conducted in 1970 . The 1970 survey study resulted in four reports on performance criteria for radiological emergency instrumentation. Three of these documents addressed criteria for emergency instrumentation at 1) reactors, (2) mixed oxide fuel fabrication plants, and (3) fuel reprocessing plants. The fourth document addressed evaluation testing and calibration methodology for these instruments.

The update of this earlier study has included a survey of thirty DOE contractors to assess current emergency preparedness capabilities. This survey showed that in approximately onehalf of the criteria surveyed in both 1970 and 1980 there was a significant improvement. Approximately $30 \%$ of the criteria that were in- cluded in both surveys showed some improvement, and $20 \%$ indicated a decline in emergency response capabilities.

A draft report covering the results of the survey was completed in FY 1983. Following an extensive review, the draft report was revised to facilitate the comparison of data with the earlier report and to improve the presentation of results. This included a reanalysis of some of the earlier data. The report was completed and published during Fy 1984.

The review has also shown that the earlier instrument performance criteria should be updated to reflect the current state-of-theart. Refinements have been made in models for atmospheric transport, and new and improved instruments have become available, including the current trend toward digital instruments. Several standards have been written or are in preparation covering instrument performance under a variety of condjtions. Recommendations on emergency preparedness instrumentation will be updated to reflect changes in DOE facility types and instrument performance criteria as reflected ir. standards and state-of-the-art instrumentation.

Updating of the reports was started in Fy 1983 with preparation of sections of a draft document on generic requirements for emergency instrument preparedness at DOE facilities. These sections were edited and reorganized during $F Y$ 1984, but most of the effort was directed toward completion of the survey report. 
During Fy 1985, efforts will be directed toward onsite evaluation of emergency instrument preparedness at selected OOE facilities. This will provide a basis for reassessment of data in the survey report, will provide a realistic assessment of emergency instrumentation capabilities, and will form a basis for recommendations in the generic document. This will aiso assist in identification of requirements at specific facility types.

DOE PROGRAM FOR IMPROVING ATR SAMPLING ANO MONITORING

\section{J. L. Kenoyer, B. L. Murphy, A. Y. Robinson}

The objective of this task is to provide a continuing effort to identify and resolve problems with work environment air sampling and monitoring at DOE and DOE contractor facilities. Workplace air sampling and monitoring are comonly used as indications of the effectiveness of engineered controls on dispersible radioactive materiais. Less commonly, air sampling and monitoring results are used to estimate persannel exposure to airborne radionuclides. Although the accuracy and precision of existing air sampling and monitoring techniques are typically not adequate for this purpose, changes in the recommendations of the International Commission on Radiological Protection (ICRP) may place increased emphasis on the use of air sampling to assess internal dose.

During FY 1984, a draft standard was developed in association with the ANSI N42.17 evaluation work being performed for DOE and NRC. This draft standard entitled "Perfomance Specifications for Airborne Radioactivity Monitoring Instrumentation" includes testing criteria and procedures that are directly related to the needs of this project. Areas discussed in this standard include general, environmental, electronic, radiological, and airflow requirements. The draft standard has been reviewed once by members of the ANSI working group and by other interested manufacturers, users, and regulators not on the committee. The changes recominended by these reviewers will be incorporated into the text, and the draft standard will be reviewed again by the working group eariy in FY 1985. A technical evaluation of the standard is pianned in FY 1985.

A detailed air samping and monitoring questionnaire was sent to nOE contractors through the respective field offices in Fy 1984. This questionnaire covered eight aspects of workplace air sampling and monitoring:

- Documentation

- General Practices

- Continuous Sampling

- Personnel Air Sampling

- Sample Handling and Analysis

- Air Monitoring Practices
- Air Monitor Calibration

- Development Needs

The results of the project were developed into a draft report entitled "DOE Workplace Air Sampling and Monitoring Practices." The report, which will be published in FY 1985, summarizes current air monitoring/sampling practices from twenty DOE or DOE contractor facilities. Areas identified for improvement and/or closer inspection include derivation of MPC-hr limits; particle size and solubility determination; effect of humidity, pressure, and temperature on air monitoring instruments; and improved capability for realtime alpha and tritium monitoring.

A subcontract with Lawrence Livermore National Laboratory to develop a highiy sensitive transuranic aerosol monitor for use in the workplace environment is in place. The system may have the capability of measuring airborne levels of $239 \mathrm{pu}$ under quasi-realtime conditions with a sensitivity level of s0.5 MPC-hr. The concepts have been developed, and effort is under way to build the prototype that will be field tested. The development of the collection system, the controi circuitry, and software is presently under way.

DOE ALARA (As Low As Reasonably Achievable) UPGRADE

L. H. Munson, D. P. Higby, R. L. Kathren

This task was injtiated in FY 1983 with the objective to review and upgrade DOE guidance on ALARA. The existing manual is being revised, including the development of additional detailed guidance as necessary. A draft revision of the manual, emphasizing the application of ALARA and providing decision trees for development of ALARA programs, was completed in FY 1984 and transmitted to the sponsor. Following a review of the manual, it was decided to expand the scope of each of the sections with the ultimate goa $i$ of a single definitive document describing the elements necessary for an effective ALARA program and methods for implementation. Future efforts will center on expansion and completion of the sections on Administration, Goal Setting and Program Evaluation, and Conduct of Operations. In addition, the format and basis information for an in-depth treatment on radiological design for ALARA will be developed for expansion of the Radiological Design Section.

EVALUATION AND UPGRADE OF DOE INTERNAL. DOSIMETRY PRACTICES

B. L. Murphy, K. R. Heid, R. J. Traub, A. V. Robinson

The objectives of this program are to (1) evalwate significant problems that affect internal 
dosimetry practices at $\mathrm{DOE} / 0 \mathrm{OE}$ contractor facilities, (2) provide recomendations for improvements in internal dosimetry programs, and (3) develop improved analyticat (e.g., bioassay) and dose evaluation techniques. Reports wi) 1 be prepared on current status of internal dosimetry, dose eva?uation techniques, improvements in analytical capabilities, application of new promising concepts for internal dosimetry, and recommended internal dosimetry practices.

During FY 1984, a questionnaire concerning the internal dosimetry practices at DOE facilities sent to all DOE/DOE contractor facilities was analyzed, and a report has been drafted. A preitiminary report on the findings was presented at the Twenty-Ninth Annua Meeting of the Health Physics Society.

The responses to the questionnaire indicated that the individuals responsibie for internal dosimetry at DOE facilities are concerned about the accuracy and reliability of the meth. ods used to estimate uptakes of radioactive materiats and the radiation doses resulting from the uptakes. Specifically, the radiation detection methods do not have the spatial resolution needed to quantify radioactive materiais in individual body organs, except for a few instances such as iodine in the thyroid. In addition, the mathematical models that describe the distribution of radioactive material within the body are not sufficientiy accurate to predict the organ depositions in specific individuals. A final concern is that the method used to assign a date of intake when the actual date is unknown will resu?t in large errors.

Three literature searches were conducted and documented in Fy 1984 via letter reports. First, review of the available literature was conducted in order to estimate the magnitude of the error associated with internal dosimetry. The sources of errors were placed into seven categories: bioassay, uptake models, organ masses, energy distributions, time of uptake, nonuniform distribution of activity within body organs, and the undetected annual dose commitment due to bioassay interval. The magnitude of the errors for each error source was estimated based upon estimates from the scientific literature. The individual errors ranged from $10 \%$ to greater than 100\%. The total error associated with internal dosimetry was not estimated because it was not known to what extent the individual errors were independent, randor events.

Second, the effectiveness of fecal analysis in a bioassay program was reviewed. It was concluded that, for some isotopes, fecal analysis provided better sensitfvity than other techniques, but careful attention to exposure history, metabolic parameters, and physical form of the isotopes is necessary to enhance the utitization of the technique.
Third, the correlation between personal air samplers and internal dose estimations was investigated. The error associated with personal air samplers was found to be signifi. cant. Considerable improvements in the interpretation of sampling resuits and the cor. relation with biological deposition are required before the data can be effectively used for internal dosimetry practices.

\section{STANDARDS EVALUATION}

J. M. Seiby, B. L. Murphy, K. R. Heid, J. P. Coriey

The objective of this task is to provide a timely technical evaluation of national and internationa? occupational exposure recommend. ations, standards, and regulations to determine in particular their technical accuracy, their impact on DOE operations, and compatibility with DOE operations and orders. As appropriate, technical expertise is drawn from other DOE contractor laboratories to as.. sist in the evaluation. In FY 1984, evaluations were performed of ICRP Publication 26; proposed NRC revision to 10 CFR 20; proposed EPA revision to Guidance to the Federal Agencies on Occupational Radiation Protection Transuranium Elements in the General Environment (EPA); Clean Air Act (EPA); draft NCRP comittee report; draft HHS Radioepideniological tabies and numerous ISO, IAEA, NEA, and ANSI standards. A Technical Advisory Committee consisting of representatives from several DOE contractor laboratories was formed to assist with evaluations that specifically affected occupational exposure regulations.

HEALTH PHYSICS TECHNICIAN TRAINING CHARACTERIZATION FOR DOE CONTRACTORS

\section{J. A. Maclellan, J. M. Selby, B. L. Murphy}

The health physics technician plays an essential role in the control of radiological hazards at DOE facilities. Recent staff reduc. tions at contractor-operated DOE facilities raise the possibility of a corresponding reduction in radiological control abilities. With this in mind, the DOE Office of Nuclear Safety requested a survey of the current. status and trends in technician-level radiation safety manpower and training among $\mathrm{DOE}$ contractors. A detailed questionnaire was sent to DOE field offices for transmittal to appropriate DOE contractors. The responses to the questionnaire, along with other requested supplemental material, were analyzed and reported in two phases.

Phase I ended with the completion of the ORAU report "Manpower Trends and Training Requirements for Radiation Protection Personnel in the DOE Contractor System." The "Phase II" report, which describes recomendations con- 
cerning training requirements, has been completed and is currently with the sponsor. Jay Maclelian presented the findings of this survey to the Training Resources and Data Exchange meeting in Las Vegas, July 9-10, 1984.

\section{RADIATION RECOROS SYSTEMS AT DOE FACILITIES}

\section{R. J. Traub, B. L. Murphy}

Two surveys were performed to determine the present status of radiation records systems at DOE/DOE contractor facilities. A questionnaire was sent to all DOE facilities through $D O E / H C$ and the respective field offices. The questionnaire dealt with the extent to wich computer data bases were used for radiation exposure records and the time required to obtain certain types of information concerning radiation exposure histories. The responses to the questionnaire indicated that, of the thirty-six facilities who responded, twentythree used computer systems to assist in maintaining the records. Most of the cornputer systems were described as having been developed in-house. The time required to retrieve information from the records systems varies from facility to facility; the variation among facilities exists because not a 11 facilities have completed entering their data into computer files.

A telephone survey was also conducted to determine the impact upon the records personne? of increasing the frequency of reporting dose sumnary data from annually to quarterly. The responses received indicate that, in addition to increased costs due to more frequent reporting, there may be substantial costs associated with changes in external and interna? dosimetry programs. The changes in the programs would be required in order to provide the data for the more frequent reports.

\section{EXTREMITY DOSE MEASUREMENTS EVALUATION AND} UPGRADING

\section{B. L. Murphy, P. L. Roberson, J. A. Maclelian}

The objective of this progran is to evaluate proposed regulations. New extremity dosime- try dosimeters and instruments in current use at DOE laboratories for monitoring personne? extrenity exposure and report on (1) current status of extremity dosimetry systems, including response characteristics; (2) development of calibration systems and procedures for instruments and dosimeters; (3) application of new promising concepts for extremity measurements; (4) status of occupational protection standards related to extremity dosimetry and evaluation of needs for new or improved guidance and impact on DOE operations; and (5) preparation of operations manuals for recommended systems.

This prograin will evaluate the significant problems that affect field measurement of extremity dose due to beta, gamma, and meutron radiation. Particular attention will be given to difficulties in complying with present or psystems will be designed for possible implementation at DOE facilities.

During FY 1984, a questionnaire sent to 00E/ DOE contractor facilities concerning the current status of extremity dosimetry was evaluated. This evaluation indicated a need to improve dosimeters for the measurement of the shallow dose equivalent for extremities and to provide guidance on the selection, use, and placement of extremity dosimeters; the results of the study will be published in FY 1985.

Studies to determine an appropriate phantom for the performance testing of extremity dosimeters were initiated in FY 1984. These studies will also provide data to determine the significance of $\mathrm{C}_{x}$ factor for extremity dosimetry. Data from these studies will be utilized in draft HPSSC/ANSI 13.32 "Standard for the Performance Testing of Personne? Dosimetry Systems." 



\section{- Technical Guidelines for Radiological Calibrations}

This program continues to provide technical guidelines for personnel dosimetry calibration procedures at DOE laboratories. This information and guidance will help to optimize equipment and procedures for radiological calibrations. The current tasks include developing a performance data base for radiation protection instruments and preparing guidelines for their calibration. In addition, an intercomparison program for laboratory calibrations is under way.

TECHNICAL GUIDELINES FOR RADIOLOGICAL CALIBRATIOISS

3. C. McDonald, P. L. Roberson, K. L. Swinth

The objectives of this program are to establish guidelines for the calibration of personnel dosimeters and radiation protection instruments. This guidance will help O0E laboratories institute optimum techniques for radiological calibrations in a cost effective and prompt manner. It witl also establish a more uniform approach to dosimetry by reducing site-dependent differences in reported personnel doses that may arise from calibration differences. The accomplishments of the program are described below.

A data base is being developed to characterize the calibration techniques, the types, and the performance of instruments currently used at DOE facilities. A survey of DOE facilities and a compilation of data available from Hanford experience and data from related projects have been completed. Site visits to several major DOE 1aboratories and use of related data from the laboratories are planned.

Experience gained from the ongoing evaiuation of ANSI N42.17D2 and additional evaluations deemed recessary will be used to determine instrument performance. Information has been tabulated on typical instrument performance, existing calibration capabilities, and calibration requirements. The frequency of calibration, type of radiation, dose, and energy have been investigated.

When new or more rigorous calibration requirements are established for instruments, tests will be performed to assure that they are practical. Uniform calibration requirements have not been established for many instruments. When they are established, the entire range of influencing parameters must be considered, such as energy response, temperature response, and environmental influences.

At the request of the DOE Office of Nuclear Safety, Health Physics Group, PNL is conducting an intercomparison study of radiological calibration standards. The intent of the program is to identify and eliminate sources of variation in calibration procedures and techniques. This study, similar to one conducted in Europe, is expected to encourage greater communication between laboratories regarding field-tested procedures to be used to solve calibration problems specific to OOE facilities. Further, the program will provide DOE laboratories an opportunity to obtain independent checks of calibration standards.

The intercomparison program involves crosschecks of both instrument and dosimeter calibrations. Laboratories have the opportunity to participate in the following four categories of testing: high energy photon, low energy photon, beta, and fast neutron. Laboratories participating in the study have been shipped a set of instruments and dosimeters and have been requested to expose the devices to their calibration sources at specified doses. The laboratories have been reporting the instrument response and returning the dosimeters to PNL for readout. Preliminary results are available. When the study is complete, the intercomparison procedure will be integrated into the DOE Laboratory ACcreditation Program. 



\section{- Personnel Neutron Dosimeter Evaluation and Upgrade Program}

A program was initiated during FY 1981 with Pacific Northwest Laboratory as the lead laboratory to: (1) evaluate response characteristics of personnel neutron dosimeter systems in current use at several DOE laboratories; (2) develop improved neutron detection for use as personnel neutron dosimeters and/or portable instruments; (3) provide technical coordination of work being conducted by various laboratories, universities, and private companies; and (4) maintain program quality and timeliness.

PERSONNEL NEUTRON DOSIMETER EVALUATION AND UPGRADE PROGRAM

L. G. Faust, D. E. Hadiock, L. H.

Brackenbush, M. A. Parkhurst, J. C. McDonald, R. I. Scherpelz, D. L. Haggard, G. H. R. Endres

The objective of this program is to provide a continuing effort to resolve problems of assessing personnel neutron dose at DOE facilities. Progress during FY 1981, FY 1982, and FY 1983 included: an assessment of the current status of personnel neutron dosimeter systems at DOE facilities; recommendations on methods of calibrating personnel neutron dosimeters; and continuing development of severa) concepts that show promise of upgrading the state-of-the-art in personnel neutron dosimetry. The program is continuing tasks to improve personnel neutron dosimetry and dosimetry systems for DOE and its contractors. Program accomplishments are publicized, and commercial vendors are encouraged to participate through technology transfers, which could lead to commercialization of dosimeters and/or instruments.

During FY 1984, PNL and its subcontractors conducted neutror dosimetry research and development or other activities in nine principal areas: (1) technoloay transfer, (2) prototype evaluation, (3) field measurements, (4) CR-39 (Columbia Resin-39) plastic technology, (5) combination thermoluminescent dosimeter (TLD)/ track etch dosimeter (TED) concepts, (6) total dosimeter dosimetry, (7) high energy neutron ( $>5 \mathrm{MeV}$ ) dosimetry, (8) neutron depth dose characterization, and (9) resonance ionization spectroscopy dosimetry.

Transfer of program developments to field operations is being continued through the use of contractor meetings and workshops. Prototype dosimeters and instruments are being developed from proof-of-principle concepts and are being evaluated to determine their potential for improving existing capability.

Field measurements of neutron dose and spectra are being conducted at several DOE laboratories and commercial power reactors. This information, along with the measured responses of new devices, will allow determination of the accuracy of field neutron measurements and is published as it becomes available.

Field implementation of a superior neutron dosimeter that uses TLDS in combination with TEOs is being accomplished. of all the track etch materials now available, the one with the trade name $C R-39$ is one of the best for neutron dosimetry purposes. During the last year, the unifomity, long-term stability, and radiation response characteristics of $C R-39$ have been established to a great extent. In particular, the energy response from approximately $25 \mathrm{keV}$ to $18 \mathrm{MeV}$ has been completed, and certain unexpected responses resulting from carbon breakup due to neutrons with energies around $16 \mathrm{MeV}$ have been identified. Work is currently under way on investigating the lower limits of neutron sensitivity, both in dose and energy. In addition, the University of California at Berkeley, the University of Connecticut at Storrs, Lawrence Livemore National Laboratory, and PNL have worked together to: (1) produce a chemical processing system that can handle large numbers of TEDs during any one processing period; (2) improve the manufacturing process to make dosimetry grade CR-39; (3) evaluate the long- term properties (fading, change in sensitivity) of CR-39; and (4) develop improved CR-39 monomers.

Development of total dose meter (rem-meter) concepts is continuing through the use of tissue equivalent proportional counter (TEPC) technology. During the last year, PNL has demonstrated the feasibility of making simultaneous neutron and gamma dose measurements with a single cylindrical TEPC. Simple algorithms have been derived to detemine quality factors and dose equivalent from spherical counters and are currently being developed for cylindrical detectors. This is being accomplished by making a series of exposures to monoenergetic neutrons with energies ranging from $100 \mathrm{keV}$ to $20 \mathrm{MeV}$. Once this relationship is known, an inexpensive microcomputer will be programed to determine dose and dose equivalent for mixed radiation fields. In addition, a breadboard device was designed, built, and connected to the detector(s) to prove the feasibility of the concept. During FY 1985, EG\&G/Santa Barbara, will be working closely with PNL to develop an operational prototype to fit DOE's needs. 
Other selected concepts potentially capable of state-of-the-art improvements in personnel neutron dosinetry were also investigated during the year.

- A tissue-equivalent phantom was exposed to beams of neutrons, and the depth-dose profile inside the phantom was measured using several sina?1 TEPCs. The exposures were performed using monoenergetic neutrons generated by a Van de Graaff positive ion accelerator. Improvements to the commonly-used tabulations of flux-to-dose conversion factors were then calculated by PNL using profiles of neutron flux, dose, and dose equivalent profiles in tissue-equivalent phantoms exposed to the beams of monoenergetic neutrons.

- PNL continued to improve the accuracy and efficiency of personnel dosimetry for DOE laboratory workers who may be exposed to high energy neutrons (greater than $5 \mathrm{MeV}$ ). Few techniques are available for the measurement of such high energy neutrons. However, the response of severa? dosineter types (track etch dosimeters, TLDs, portable rem-meters, etc.) for both monoenergetic neutrons and neutron spectra encountered at DOE facilities, such as the Bevalac accelerator at Lawrence Berkeley Laboratory, was determined during FY 1984.

- The measurement of low levels of neutron exposure is a matter of renewed concern, especially at low neutron energies where no suitable method currently exists. New information on relative biological effectiveness calis for reduction of the minimum measurable limit in monitoring the neutron exposures received by personne? in th: nuclear industry. To achieve the desirad 1 imits, in turn, requires the development. of a new type of neutron dosimeter. Atom iciences, Inc., Oak Ridge, Tennessee, is iniestigating a system to count xenon atoms $i \in$ leased from a solid matrix material by collision events which correlate with neutron dose. The xenon atoms released during the period of exposure to neutrons would be counted in a Taboratory "reader" using resonance ionization spectroscopy.

To date PNL and its subcontractors have:

- recommended personnel neutron dosimeter calibration procedures

- measured response characteristics of current personnel neutron dosimeters at. DOE facilities

- developed a combination themotuminescent/track etch dosimeter

- developed a new dose meter using tissueequivalent proportional detector technology.

Future accomplishments include evaluation of new neutron dosimeter prototypes, implementation of new dosimetry systems and programs, fieid measurements of dose equivalent and spectra including accelerators, and technolo. gy transfer to comercia? vendors. 


\section{- Beta Measurement Evaluation and Upgrade}

This program focuses on the resolution of problems associated with the field measurement of the beta dose component at DOE facilities. Little attention has been paid to improving beta measurements during the past fifteen years. The change in DOE programs, including increased efforts in improved waste management and D\&D facilities, coupled with beta measurement problems identified at Three Mile Island, has heightened DOE's awareness for the need to improve beta measurements. In FY 1982, work was initiated to provide a continuing effort to identify problems associated with beta dose assessment at DOE facilities. The problems identified resulted in the development of this program. The investigation includes (1) an assessment of measurement systems now in use, (2) development of improved calibration systems and procedures, (3) application of innovative beta dosimetry concepts, (4) investigation of new instruments or concepts for monitoring and spectroscopy, and (5) development of recommendations to assure an adequate beta measurement program within DOE facilities.

\section{BETA MEASUREMENT EVALUATION ANO UPGRADE}

K. L. Swinth, L. A. Rathbun, P. L. Roberson, G. W. R. Endres

The Beta Measurement Evaluation and Upgrade program was initiated to review the probiems associated with beta dosimetry practices and to develop improved procedures and measurements. The work performed in FY 1984 can be classified into four major areas: (1) current practices, (2) field measurements, (3) dosimeter development, and (4) instrument development.

During the past year, a survey of current beta measurement practices at DOE facilities was analyzed and put into report format. The draft report is currently under review with publication expected early in FY 1985. The report shows that a wide variety of beta sources exist at DOE facilities and that:

- Programs for calibration, performance testing, and quality assurance are inadequate.

- Instruments and dosimeters are not appropriately designed for beta measurement in some instances.

- Mompenetrating dose is not uniformly defined.

- Calibration sources do not exhibit one step traceability to a NBS standard and often have significantly different energy from the energy of the beta radiation measured in the field.

To date, field measurements have been perforimed at three DOE facilities, and measurements have shown that significant beta dose rates can occur. Beta spectral analyses were perforned at the sites using scintillation and solid state detectors calibrated at Pacific Northwest Laboratory (PNL).
Multielement thermoluminescent dosimeters (TLOS) were used to perform reference doserate measurements. The response of the instruments and dosimeters currently in use at the facility were compared with the measurements made using the PNL systems. Data have been analyzed and, following additional measurements during FY 1985, a report on the results will be completed.

Prototype badges were prepared under subcontract with Kansas State University using their prototype thin graphite-backed TLDs. Tests showed that the badges have a beta energy response that is relatively independent of beta energy and performed better than commonly used commercial badges. Additional evaluation of prototype badges is planned for FY 1985.

A second dosimetry system is being developed under a subcontract with International Sensor Technology (IST). This system uses an infrared laser system to heat the TLD material and leads to selected area read-out and an improved signal-to-noise ratio. A prototype system was completed during the year and delivered to PNL; however, full evaluation of the system has been delayed until acquisition and installation of a suitable computer system can be completed. Under subcontract, IST has continued to refine this read-out technique. This has included improved laser read-out stability and an improved beam profile to permit read-out of a larger area of the TLD. It will enchance reproducibility and lower the detection level; it will be incorporated into our read-out system in the coming year.

The use of photoacoustic read-out fiber optics was investigated for beta dosimetry. Tests showed some promise, but results were ambiguous. Initial experiments were also perfomed on optically stimulated read-out of TLDs; further tests on both photoacoustic read-out and optically stimulated read-out are planned during the coming fiscal year. 
thick depletion region free of charge trapUnder subcontract with Lawrence Livermore $\mathrm{Na}-$ tional Laboratory, the use of silicon detectors as a solid-state analog of the extrapolation chamber was investigated. The results were partially successful, but the high purity of currently available detectors provides a ping centers with iow bias voltages. A strong dependence on collection region th. ckness with bias voltage is required for suc cessful implementation of this concept. To successfully develop such a detector would require an expensive material deveiopment project. 


\section{- Department of Energy Laboratory Accreditation Program for Occupational Exposure Measurements}

This program provides research support for the Department of Energy Laboratory Accreditation Program (DOELAP) for personnel dosimetry services. The research effort encompasses development of improved accreditation methods and operation of calibration intercomparison and measurement assurance programs for DOE laboratories. The effort for FY 1984 was primarily directed toward development of the documents required for the operation of the performance testing laboratory used in the accreditation process. These documents included the "DOE Standard for the Performance Testing of Personnel Dosimetry Systems," the "DOELAP Handbook" for program participants seeking accreditation, and the "Quality Assurance Manual" for the DOE performance testing laboratory.

DEPARTMENT OF ENERGY LABORATORY ACCREDITATION PROGRAM FOR OCCUPATIONAL EXPOSURE. MEASUREMENTS

P. L. Roberson, R. A. Fox, C. D. Hooker, B. L. Murphy

A national approach to the quality assurance and accreditation of radiological calibrations of personnel dosimetry services is being developed through the DOE Laboratory Accreditation Program (DOELAP). This program provides research support for the continuing DOELAP for personnel dosimetry services. The DOELAP research effort encompasses: (1) research into improved accreditation methods, (2) intercomparison of DOE radiological calibration standards using round-robin shipment of transport standards (instruments and sources), and (3) measurement as surance relationships with DOE calibration laboratories through irradiation of generic dosimeters and instruments.

The FY-1984 effort concentrated primarily on the preparation of the documents required for the operation of the performance testing 1aboratory. These documents were the "DOE Standard for the Performance Testing of Personnel Dosimetry Systems," the "DOELAP Handbook" and the "Quality Assurance Manual" for the DOE performance testing laboratory. All documents underwent a peer review performed by representatives of major DOE laboratories. The documents were updated in response to the review comments.

The DOE standard specifies test exposure sources and techniques for the performance evaluation of personnel dosimeters. It was based on the American National Standard, Criteria for Testing Personnel Dosimetry Performance, ANSI N13.11-1983 (ANSI-1983), and the recomendations in Guidelines for the Calibration of Personnel Dosimeters, PNL-4515 (Roberson and Holbrook, 1984). The recommendations in PNL -4515 resulted from an anal$y$ sis of ANSI N13.11 performed during the de- velopment of a data base on the performance of DOE dosimetry processors.

The participant's handbook for DOELAP was designed to be sent to DOE facilities undergoing the DOE accreditation process. It provides a short history of the development of the program, a scope of accreditation, a description of the administrative structure, and a description of the accreditation process.

The Quality Assurance Manual provides guidance for dosimeter handling, exposure sequencing, radiation field standardization, dosimeter uncertainty analysis, and quality assurance procedures. The quality assurance procedures detail classification of laboratory equipment, calibration frequencies, documentation, and relationship of laboratory standards to national standards.

Calibration laboratory upgrades were performed to prepare for research irradiations to develop improved accreditation methods and for irradiation assistance to the DOELAP performance testing laboratory. The tube for the $320-k \vee p$-ray machine was replaced. Monitor ionization chamber systems were installed for the beta and x-ray irradiation systems. A process-control system was installed for the $x$-ray laboratory. The process-control system will record irradiation parameters for dosimeter exposures and is an integral part of the quality assurance effort for DOELAP.

\section{References}

American National Standards Institute (ANSI). 1983. American National Standard, Criteria for Testing Personnel Dosimetry Performance. ANSI N13.11-1983, New York, New York.

Roberson, P. L. and K. L. Holbrook. 1984. Guidelines for the Calibration of Personnel Dosimeters. PNL-4515, Pacific Northwest Laboratory, Richland, Washington. 

Operational Safety 



\section{OPERATIONAL. SAFETY}

- Assurance Program for Remedial Action

- Environmental Protection, Support and Assistance

- Hazardous Waste Risk Assessment

\section{- Policy Studies-Radiation}

The responsibility of the Department of Energy (DOE) Office of Operational Safety is to assure that activities and installations of the Department and its contractors are in full compliance with DOE environmental protection, safety and health protection policies and applicable federal, state, and local environmental, safety and health (ES\&H) standards and regulations; to provide technical support to DOE ES\&H programs and assurance systems; and to ensure that all DOE-controlled activities are conducted in a manner that will maintain risks to the safety and health of the public and employees at acceptably low levels, and that will provide for adequate protection of property and the environment. 



\section{- Assurance Program for Remedial Action}

This project was initiated in the first quarter of FY 1984 to provide technical assistance to the DOE Office of Operational Safety (OOS) in developing and implementing its Assurance Program for Remedial Action (APRA), i.e., overview of the DOE remedial action programs. During this first year of the project, the technical assistance included report and procedure reviews, and preparation of the technical content for a draft DOE Order on APRA. Information-gathering visits were made to three of the DOE Remedial Action program offices. Pacific Northwest Laboratory (PNL) developed criteria for generic program guidance review and a bibliographic data base. Draft reports were prepared on: reviews of the Formerly Utilized Sites Remedial Action Program (FUSRAP) guidance documents; radiological survey protocols with respect to risk assessment; radiological assessment methodologies at uranium mill tailings vicinity properties; radiological standards and guidelines pertinent to DOE's remedial action programs. PNL also provided technical support and assistance to OOS in the APRA appraisal of the FUSRAP office (DOE/OR), including participation in preappraisal visits to four FUSRAP sites in New York and New Jersey.

TECHNICAL ASSISTANCE TO DOE/OOS ASSURANCE PROGRAM FOR REMEDIAL ACTION (APRA)

D. H. Denham; F. T. Cross; W. E. Kennedy, itr.; S. Marks; J. K. Soldat; R. D. Stenner

The objective of this project is to assist the Department of Energy (DOE) Office of Operationa) Safety (OOS) in developing and implementing its Assurance Program for Remedial Action (APRA). The intent is to provide technica? support to $00 \mathrm{~s}$ in its role of overviewing to assure, by review and appraisa1, the successful implementation and completion of DOE's four remedial action programs:

- Formerly Utilized Sites Remedial Action Program (FUSRAP)

- Surplus Facilities Management Program (SFMP)

- Uranium Mill Tailings Remedial Action Program (UMTRAP)

- Grand Junction Remedial Action Program (GJRAP)

$00 S$ recognizes that the APRA support contractors may also have input to individual remedial action projects. To avoid any potential conflicts with respect to these services, oos makes adjustments accordingly in requesting support from certain APRA contractors on specific remedial action projects. For this reason, this project has not provided assistance in the overview of SFMP.

The project includes five tasks: general technical support and assistance, assistance in conducting ES\&H reviews and appraisals, review of existing and proposed radiological standards, evaluation of risk assessment methodologies, and overall project management. Specific task areas addressed in $\breve{F} Y 1984$ in. cluded:
- reviews and comments on proposed project direction in consultation with OOS and other support contractors;

- assistance with developing a DOE Order on APRA;

- assistance with planning and conducting the first OOS (A.PRA) appraisal of a DOE remedial action program office:

- reviews of existing and proposed radiological standards and guidelines for use in DOE's remedial action programs;

- reviews of risk assessment practices with respect to remedial action programs, including reviews of existing radiological survey protocols; and,

- preparation of generic program guidance review criteria.

APRA PROJECT DIRECTION

D. H. Denham

As major input to the direction of this project in FY 1984, PNL provided DOS with an overall project plan; a topical outline for procedura 1, operational, and verificational overview; and draft material for a DOE Order.

ES\&H REVIEWS AND APPRAISALS

R. D. Stenner

The major activity of this task was the deveiopment of generic program guidance review criteria. Based on these criteria, reviews were completed of the program plan documents for UMTRAP and all of the program guidance documents for FUSRAP. In addition to these re- 
views, PNL also provided support for the OOS appraisat (including preappraisal visits to specific FUSRAP remedial action sites) of the FUSRAP office.

\section{RADIOLOGICAL STANDARDS REVIEH}

J. K. Soldat

This task has involved active participation in residual contamination criteria workshops sponsored by DOE/DP (DOE Headquarters, January 17-19), and DOE/NE (Gai thersburg, Maryland, February 21-23; Argonne, Illinois, June 26-27). Preliminary results of the standards reviews were summarized in a series of tables, and a brief narrative was provided to o0s in the summer.

\section{RISK ASSESSMENT REVIEWS}

S. Marks

Two draft technical reports were prepared under this task during the fiscal year: "A Review of Radiological Assessment Methodolngies for Uranium Mili TaiTings at Vicinity Properties" and "A Review of Radiological Survey Techniques from DOE's Remedial Action Programs Relative to Performing Risk Assessments." Other activities of this task included responding to Congressional inguiries regarding risk assessment and providing ad hoc reviens of risk assessment practices for oos staff upon request. 


\section{- Environmental Protection Support and Assistance}

The Pacific Northwest Laboratory continued to provide technical assistance to DOE's Office of Operational Safety (OOS) in the area of environmental protection. PNL's technical support included extensive planning and assistance in preparing for the Fifth DOE Environmental Protection Information Meeting and assistance in preparing and reviewing interim DOE guidance for estimating public radiation doses. A data evaluation report was prepared and published concerning the DOE Quality Assessment Program for environmental monitoring, and a report summarizing the radioactive effluents from DOE facilities was prepared.

ENVIRONMENTAL PROTECTION SUPPORT AND ASSISTANCE TO DOE/OOS

W. E. Kennedy, Jr.; R. E. Jaquish; J. P. Corley; R. C. Adams; K. A. Hawley; K. L. Imhoff; R. R. Kinnison; E. B. Moore, Jr.; J. R. Raymond; J. K. Soldat; E. C. Watson

The Environmental Protection Support and Assistance Project provides the Department of Energy's Office of Operational Safety (00S) with technical support to assist OOS in accomplishing its environmental protection objectives. Several ongoing tasks are funded concurrentiy, at the request of $00 \mathrm{~S}$, to provide flexibility in response to management priorities as they evolve. Task areas addressed during 1984 included:

- participation in the DOE Renedial Action Criteria Workshops to determine DOE remedial action criteria for application to DOE's fomerly utilized sites and remote surplus facilities

- participation in Advisory Group meetings of the International Atomic Energy Agency (IAEA) concerning assessments in relation to 1 imiting releases of radioactive effluents to the environment

- assistance to 00S in support of the Fifth DOE Environmental Protection Information meeting

- initial development of revised sections of the updated Effluent and Environmental Monitoring Guide

- assistance in preparing and reviewing interim DOE guidance for estimating public radiation doses

- development of quidelines for a DOE ground-water protection program

- development of a ground-water monitoring harldbook

- completion and pubtication of an annuat sumbary of environmental effluents from operating DOE sites
- publication of a DOE quality assessment program data evaluation for environmental monitoring data

EFFLUENT AND ENVIRONMENTAL MONITORING GUIDES

J. P. Corley, J. K. Soldat, E. C. Watson

The environmental monitoring guide, a companion document to the effluent guide, is in the process of being revised and updated. This guide was written to promote greater uniformity in DOE environmental radiological moni. toring programs. Additional modifications resulting from proposed revisions to DOE guidance for estimating public radiation doses were under consideration.

QUAL ITY ASSURANCE FOR DOE ENVIRONMENTAL AND EFFLLUENT MONITORING

\section{R. E. Jaquish, R. R. Kinnison}

PNL continued to support the DOE Environmental and Effluent Monitoring Quality Assessment Program by continuing ongoing discussions with the Environmental Heasurenents Laboratory in New York. A document entitled "U.S. Department of Energy Quality Assessment Program Data Evaluation Report" was issued. Information for the next QA Steering Committee meeting, to occur during the Fifth $D O E$ Environmental Protection Information meeting, was prepared.

\section{ENVIRONMENTAL DOSE ASSESSMENT METHODOLOGY}

$$
\text { ๖. P. Corley }
$$

Initial efforts to produce a draft document concerning interim guidance for conducting public dose evaluations for environmental effluents from DOE sites were begun. These ef forts combined contributions from PNL and Los Alamos National Laboratory in considering a change to the ICRP 30 dosimetry system for public dose estimates. Final interim guidance is scheduled to be completed early in 1985. 


\section{ANNUAL ENVIRONMENTAL SUMMARY REPORT}

\section{K. A. Hawley}

Each year, PNL provides for DOE management a summary of the information contained in the annual enviromimental reports generated by the DOE nuclear facility contractors. The 1983 summary (based on contractor documents received in May of 1984) was completed in draft form and issued for field review. Initial coments were collected from the DOE field organizations.

\section{ENVIRONMENTAL DATA REPORTING}

E. B. Moore, ur.

Data collection efforts for three DOE nuclear sites began in support of the development of a series of Environmental Summary Profiles and Environmental Profile data bases. A detailed outline for the data base was prepared and reviewed. This effort is intended to uttimately provide $00 E / 00 S$ with current information about the environmental status of each DOE site. The information will be stored in a data base that will permit easy access and modification by both PNL and OOS staff.

\section{GROUNDWATER PROTECTION PROGRAM}

\section{J. R. Raymond}

A draft groundwater protection report was developed and reviewed by 005 staff. This report is entitled "Guidelines for a U.S. Department of Energy Ground-Water Protection Program." A second document entitled "Guidelines for Ground-Water Monitoring Programs at U.S. Department of Energy Facilities" was revised after initial review comments were received. Both of these documents will be completed during 1985.

FIFTH DOE ENVIRONMENTAL PROTECTION INFORMATION MEETING

J. P. Corley; W. E. Kennedy, Jr.
A Program Committee was established for reviewing the abstracts submitted in respons a to the call for papers for the Fifth DOE $\equiv 1$ vironmentai Protection Information Meetirif. Registration packages were mailed to all meeting participants and initial arrangements were made for producing the camera-ready sopy of the meeting proceedings. PNL staff pr)vided additional administrative and suppor: assistance to OOS in preparing for this $j$ portant meeting.

\section{RISK VALUE METHODOLOGY DEVELOPMENT}

R. C. Adams, K. L. Imhoff

A risk value methodology was developed and modified to fit the needs of DOE in determining a priority ranking of proposed Enviro'.. mental Safety and Heal th upgrade projects. This methodology was applied to the FY 19315 budget requests and the resulting ranking was used by DOE in determining the final budga:-. Future tasks include providing formal docu.. mentation of the computerized methodology.

\section{SPECIAL ASSISTANCE}

W. E. Kennedy, Jr.; J. P. Corley

This special assistance task provides for quick responses to issues that may fall ols:side the scope of other established tasks. Technical support is given on an ad hoc batsis as requested. During 1984 , the activitie; conducted under this task included: parti.. cipation in the DOE Remedial Action Crite a Workshops to detemine DOE remedial action criteria for application to DOE's formerl utilized sites and remote surplus facilities, participation in Advisory Group meetings $0^{*}$ the International Atomic Energy Agency (IAl: $A$ ) concerning assessments in retation to limit:ing releases of radioactive effluents to the environment, and continued reviews of proposed regulatory changes that may affect $D O E$ operations. 


\section{- Hazardous Waste Risk Assessment}

Pacific Northwest Laboratory continued to provide technical assistance to the DOE Office of Operational Safety (OOS) in the area of risk assessment for hazardous and radioactive mixed waste management. The overall objective of this work is to provide technical assistance to OOS in developing strategies for bringing DOE facilities into compliance with the technical intent of the Resource Conservation and Recovery Act (RCRA) and the Comprehensive Environmental Response, Compensation, and Liability Act (CERCLA). Major efforts during FY 1984 included: (1) completion of an effort to develop and conduct a workshop on groundwater monitoring under RCRA; (2) selection and assembly of a team of experts to conduct a technical review of DOE field office groundwater monitoring plans; (3) provision of technical input for developing DOE guidance on CERCLA; (4) initiation of work to modify the EPA Hazard Ranking System to include assessment of radiological hazards; (5) initiation of work to develop an objective, scientifically based methodology for DOE management to use in establishing priorities for conducting site assessments and possibly remediation; and (6) initiation of an open literature technical review of documented contamination of groundwater by organics.

\section{GROUNDWATER MONITORING WORKSHOP}

B. L. Steelman, R. Schalla, J. M. Meuser, D. A. Myers

During the early part of FY 1984, DOE field offices began earnest efforts to prepare implementation plans for bringing their facilities into compliance with DOE Order 5480.2 (Hazardous and Radioactive Mixed Waste Management within the framework of RCRA). While DOE field offices have extensive experience in monitoring groundwater for radiological parameters and sore other inorganics, their experience in monitoring techniques for organics in groundwater is more limited. Therefore, to assist DOE field offices in developing plans for groundwater monitoring under DOE order 5480.2, Pacific Northwest Laboratory (PNL) prepared and conducted a workshop to provide technical guidance in this area.

\section{REVIEW OF DOE FIELD OFFICE GROUNDWATER MONI-} TORING PLANS

B. L. Steelman, D. A. Myers, G. L. Mckows, P. Vanvoris, S. R. Peterson

To assist the office of Operational Safety in reviewing and commenting on DOE fieTd office groundwater monitoring plans, PNL, in concert with 005 , assenbled a team of five technical experts. Actual efforts for reviewing and commenting on the field office plans are expected to begin in the early part of fiscal year 1985.

\section{TECHNICAL GUIDANCE ON CERCLA}

\section{B. L. Steelman}

Pacific Northwest Laboratory provided $00 \mathrm{~S}$ with draft technical guidance on Comprehensive Environmental Response, Compensation and Liability Act. This guidance was then used by OOS as input to the draft DOE Order 5480.14
(Department of Energy Prograni Guidance for Comprehensive Environmental Response, Compensation, and Liability Act of 1980). A fina? version of this order is expected to be avail. able in the early part of FY 1985.

MODIFICATION OF THE EPA HAZARD RANKING SYSTEM

\section{B. A. Napier, K. A. Hawley}

The EPA Hazard Ranking System (HRS) is a simplified methodology for determining which uncontrolied hazardous waste sites may pose a high enough risk to warrant further investigation and possible remediation. However, the HRS is unable to explicitly evaluate the potential risks of radioactive material, and, therefore, its applicability to DOE sites is debatable. Without changing the basic philosophy of the HRS, PNL has initiated an effort to modify the methodology so that it can evatuate the risks of radioactive materials. A final report on this effort is expected in the early part of $F Y$ 1985, and meetings are planned to discuss the proposed modifications with EPA.

\section{METHODOLOGY FOR ESTABLISHING PRIORITY OF INACTIVE WASTE SITES}

G. Whe Jan, B. L. Stee?man, J. V. Ramsde11, D. L. Strenge, B. A. Napier

Pacific Northwest Laboratory has initiated an effort to develop an objective, scientifically based management tool for DOE to use in setting priorities among the potential risks of their inactive hazardous and radioactive mixed waste disposal facilities. The EPA Hazard Ranking System (HRS) was developed Several years ago, and, while the modified HRS will be useful in comparing the calculated priorities of DOE sites to non-DOE sites, it tends to be more subjective than necessary. The state-of-the-art in risk assessment tools is advancing rapidiy, and it 
is now possible to develop a more objective, scientifically based risk assessment methodology that will provide a better measure of the potential relative risks that sites may pose. This improved methodology, the Remedial Action Priority System, will serve as a valuable tool for DOE management to use in making funding allocations for further site investigations and possible remediations. Initial development efforts are expected to be completed in the early part of FY 1986.

ORGANICS CONTAMINATION OF GROUNDWATER

R. M. Ecker, B. L. Steelman

Because of recent public awareness and regulatory activity, the scientific and engineer- ing community has given considerable attention to contamination of groundwater by organics. At the request of $00 S$, PNL conducted a review of the open literature on contamiration of groundwater by organics and providec a brief summary of the available field dati on (1) the behavior of organics in groundwater (e.g., transport and transformation mechanisms); and (2) the extent of documentefd migration by organics from the source of contamination. A draft report has been given to 00S; a final report is expected in the early part of FY 1985. 


\section{- Policy Studies-Radiation}

The purpose of this project is to provide the Department of Energy with responsive reviews, studies, and analysis of contemporary radiation issues of a diverse nature.

\section{POLICY ANALYSIS}

W. J. Bair

During FY 1984, several staff members from Pacific Northwest Laboratory (PNL) met with a representative of the DOE office of General Counsel to inform him of the biological effects or radon and radon decay products, the interpretation of pathology in the lungs of smokers who also inhaled radon, and measurements of radon and radon decay products. PNL. also made available to the DOE legal staff who are involved in the Nevada and Utah litigations information from our research programs that would help them make effective use of severat of their consultants.

The EPA draft document, "Interim Recommendations on Doses to Persons Exposed to Transuranium Elements in the Generai Enyironment" was reviewed. An appendix to the EPA document sumarizing DOE's Enewetak experience was a1so reviewed.

A request from the Nevada Operations office led to a meeting at PNL to discuss the dosimetric data from the Marshall Islands. Participants included staff from several national laboratories and DOE. The purpose of the meeting was to review the current status of predicted and actual radiation exposures of Marshalt I5landers, particularly as these reTate to potential resettlement of Eneu Island in the Bikini Ato 11. Comparisons presented of radiation doses based on in-vivo counting measurements versus doses predicted from radionuclide intake models for Marshall Islanders at Utrik and the southern islands of Rongelap showed excellent agreement. This agreement between measured and predicted leveis consti. tutes an important overall validation of models employed in the predictions--including physical, biological, and cultural aspects of these models. An area of remaining uncertainty relates to the transuranic elements, principally plutonium and americium, where very limited bioassay data on plutonium excretion yielded much higher radiation dose values than predicted by models. This is not considered a serious complication because the transuranics are not predicted to contribute importantly to the total radiation dose, and analytical problems involving natural poionium in the urine samples seem to offer a plausible explanation of the bioassay results. Based on the best current evidence, it still seems unlikely that an Eneu resident, consuming a mix of local and imported foods (but no significant quantity from Bikini island) would exceed an exposure of 500 mrem per year.

Also under this project, two papers were prepared for presentations at meetings abroad. Both were published in the proceedings and are included in the Publications and Presentations at the end of this volume. 

Publications

and

Presentations 



\section{PUBLICATIONS}

Alvarez, J. L. 1984. "Beta Measurements in a Photon Field." Proceedings of the International Beta Dosimetry Symposium. NUREG/CP. $\overline{0} \overline{50}$, p. $\overline{187}$.

Braunlich, P., S, C. Jones, A. Abtahi, and M. delurcia. 1984. "Heating of Continuous Thermoluminescent Layers With Localized Laser Beams." Proceedings of the Seventh International conference on Solid State Dosimetry, Radiation Protection Dosimetry, 6, p. 83 .

Braunlich, P., W. Tetzlaff, J. Gasiot, and S. C. Jones. 1984. "Development of a LaserHeated TLD Reader." Proceedings of the International Beta Dosimetry Symposium. NUREG/ CP0050, p. 471 .

Fisher, D. R., A. V. Rabinson, and R. T. Hadley. 1984. "Preliminary Results of Testing Bioassay Analytical Performance Standards." PNL-SA-11656. Proceedings of the Eleventh Light Water Reactor Research Information Meeting, October 24-28, 1983, Ga ithersburg, Maryland. NUREG/CP-0n48, VoT. 6, pp. $140-147$

Fix, J. J., K. L. Soldat, and K. L. Holbrook. 1984. "Beta and Low Energy Photon Irradiation of Several Commercial Phosphors." Proceedings of the International Beta Dosimetry Symposium. NUREG/CP-0050, p. 411 .

Gillings, J. C., B. L. Murphy, C. D. Corbit, J. A. Maclellan, T. H. Essig, D. P. Higby, C. D. Hooker, G. J. Laughlin, G. A. Stoetzel, K. L. Swinth, J. M. Selby, E. J. Vallario. 1984. Characterization of Emergency Preparedness at DOE Contractor Facflities. PNL-4198.

Roberson, P. L., and K. L. Holbrook. 1984. Guidelines for the CaTibration of Personnel
Roberson, P. L., and K. L. Holbrook. 1984. Guidelines for the Calibration of Personnel Dosimeters. PNL-4515, Pacific Northwest Laboratory, Richland, Washington.

Robinson, A, V., D. R. Fisher, and R. T. Hadley. 1983. "Resuits of Round one Test of Draft ANSI Standard N13.30: Performance Criteria for Radiobioassay." Proceedings of the Twenty-Ninth Annual Conference on Bioassay, Analytical and Envirommental Chemistry, 0ctober 12-13, Seattie, washington.

Robinson, A. V., D. R. Fisher, and R. T. Hadley. 1984. Performance Testing of Radiobioassay Laboratories, Pilot Study Report. Part I: In-Vitro Measurement Testing. DOE/ NBM-1071, PNL-5107, Pacific Northwest Laboratory, Richland, Washington.

Scherpelz, R. 1., G. W. R. Endres, and P. L. Roberson. 1984. "The Application of a Multi-Element Beta Dosimeter." Proceedings of the International Beta Dosimetry Symposium. NUREG/CP-0050, D. 209 .

Selby, J. M., K. L. Swinth, C. D. Hooker, and J. L. Kenoyer. 1984. "Field Measurements and Interpretation of Geta Doses and Dose Rates." Proceedings of the Internationat Beta Dosimetry Symposium. NUREG/CP-0050, p. 157.

Simons, G. G., R. B. Stuewe, T. M. Derby, and K. D. Stansbury. 1984. "Application of Beta Spectroscopy to Beta Dosimetry Research." Proceedings of the Intermational Beta Dosimetry Symposium. NLREG/CP-0050, p. 201.

Swinth, K. L. 1984. "Beta Problems in Uranium Mining, Milling, Enrichment and Fabrication." Proceedings of the International Beta Dosimetry Symposium. NIREG/CP-0050, p. 641. 
. 


\section{PRESENTATIONS}

Bair, W. J., "All Smokers at Greater Risk from Radiation Exposure Than Nonsmokers?" 6th International Radiation Protection Association, Berlin, Federal Republic of Germany, May 7-12, 1984.

Brackenbush, L. A., "A Pocket Total Dose Meter," PNL-SA-12409. Conference on the Application of Accelerators in Residential and Industry, Denton, Texas, November 12-14, 1984.

Brackenbush, L. W., "A Pocket TEPC to Measure Dose Equivalent from Penetrating Ionizing Radiation," PNL-SA-11961. 29th Annual Meeting of the Health Physics Society, New Orleans, Louisiana, June $3-7,1984$.

Brackenbush, L. W., and G. W. R. Endres. "Personnel Monitors Utiiizing Tissue Equivalent Proportional Counters," PNL-SA-12460. Fifth Symposium on Neutron Dosimetry in Neuherberg, Germany, September 1984.

Braunlich, P., and W. Tetzlaff. "Laser Heating Techniques in Beta Thermoluminescence Dosimetry." 29th Annual Meeting of the Health Physics Society, Mew Orleans, Louisiana, June 3-7, 1984.

Cross, F. T. and W. J. Bair, "Mean Dose Versus Local Oose to the Respiratory Tract--Implications for Radiological Protection." Lung Modeling Workshop in 0xford, England sponsored by Comisision of European Communities and the National Radiation Protection Board. March $26-28,1984$.

Faust, L. G., D. E. Hadlock, and E. J. Vallario. "DOE Personnel Neutron Dosimetry Evaluation and Upgrade Program," PNL-SA-12546. Fifth Symposium on Neutron Dosimetry in Neuherberg, Federal Republic of Germany, September $17-21,1984$.

FTeming, D. M., P. L. Roberson, G. L. Carter, R. A. Fox, C. D. Hooker, J. C. McDonald, F. E. Owens, J. L. Pappin, "An Integrated Calibration Facility for Radiological Health Physics." 29th Annual Meeting of the Health Physics Society, New Orieans, Louisiana, June 3*7, 1984.

Hadley, R. T., M. A. Parkhurst, D. L. Haggard, D. E. Hadlock, "A Computerized Management System for Neutron Track Etch Dosimetry Data," PNL-5A-11949. 29th Annual Meeting of the Health Physics Society, New Orleans, Louisiaกล, June $3-7,1984$.

Hadlock, D. E., M. A. Parkhurst, D. L. Haggard, L. W. Brackenbush, L. G. Faust, "High Energy (10 MeV) Neutrons: CR-39 Track Detector Revelations," PNL-SA-11957. 29th Annual Meeting of the Health Physics Society, New Orleans, Louisiana, June 3-7, 1984.

Haggard, D. L., D. E. Hadlock, M. A. Parkhurst, "Meutron Energy Response Charac- teristics of CR-39 Using Monoenergetic Neutrons," PNL-SA-11958. 29th Annual Meeting of the Health Physics Society, New Orleans, Louisiana, June $3-7,1984$.

Hooker, C. D., B. L. Murphy, J. A. MacLellan, E. J. Vallario, "Extremity Dosimetry Evaluation and Upgrade Program," PNL-SA-11992.

29th Annual Meeting of the Health Physics Society, New Orleans, Louisiana, June 3-7, 1984.

Kathren, R. L., L. H. Munson, D. P. Higby, "Application of Risk-Cost Benefit Techniques to ALARA and De Minimis," PNL-SA-12106. 29th Annual Meeting of the Health Physics Society, New Orieans, Louisiana, June 3-7, 1984.

Kenoyer, J. L, K. L. Swinth, K. R. Mashburn, J. M. Selby, "Evaluation of a Draft Standard on Performance Specifications for Health Physics Instrumentation - Environmental Tests," PNL-SA-11481. Spring Conference of the American Society for Nondestructive Jesting in Denver, May 21-24, 1984.

Kenoyer, J. L., K. L. Swinth, K. R. Mashburn, 1. M. Selby, E. J. Vallario, M. V. Federline, "Evaluation of a Draft Standard on Performance Specifications for Health Physics Instrumentation - Environmental Tests,"

PNL-SA-11931. 29th Annual Meeting of the Health Physics Society, New Orleans, Louisiana, June 3-7, 1984.

Kenoyer, J. L, K. L. Swinth, R. L. Kathren, D. M. Fleming, J. M. Selby, E. J. Vallario, and $M$. $V$. Federline, "Results of Testing and Evaluating a Health Physics Instrument Performance Standard," PNL-SA-10985. IRPA meeting in West Berlin, May 7-12, 1984.

MacLellan, J. A.,"Health Physics Technician Training Characterization for DOE Contractors," PNL-SA-12413. Invited paper at the TRADE meeting at Las Vegas, Nevada, July $9-10,1984$.

McDonald, J. C., and F. M. Cummings, Results of High-Energy Neutron Measurements at LBL presented at European Workshop on Proportional Counter Measurements in Health Physics, May 16-18, 1984 in Homburg, West Germany by K. L. Swinth.

Murphy, B. L, J. M. Pisarcik, K. L. Swinth, and E. J. Vallario. "An Evaluation of Current Practices in Beta Dosimetry at DOE Facilities," PNL-SA-11945. 29th Annual Meeting of the Health Physics Society, New Orleans, Louisiana, June 3-7, 1984.

Parkhurst, M. A., D. L. Haggard, P. L. Tomeraasen, D. E. Hadiock, "Trials and Tribulations of Processing CR-39 for Neutron Dosintetry," PNL-SA-11957. 29th Annual Meeting of the Health Physics Society, New Orleans, Louisiana, June 3-7, 1984. 
Pisarcik, J. M, A. V. Robinson, K. L. Swinth, and B. L. Murphy. "Selection and Use of Radiation-Measuring Instruments for Emergency Preparedness Programs," PNL-SA-11944. 29th Annual Meeting of the Health Physics Society, New Orleans, Louisiana, June 3-7, 1984.

Roberson, P. L., C. D. Hooker, J. C. McDonald, 3. L. Pappin, "Experience with the Buchler Secondary Beta Standards," PNL-SA-11945. 29th Annual Meeting of the Health Physics Society, New Orieans, Louisiana, Jurie 3-7, 1984.

Roberson, P. L., C. D. Hooker, J. C. McDonald, J. M. Selby, and E. J. Vallario, "Department of Energy Laboratory Accreditation Program," PNL-\$A-12029. 29th Annual Meeting of the Health Physics Society, New Orleans, Louisiana, June 3-7, 1984.

Robinson, A. V., D. R. Fisher, and R. T Hadley. 1984. "A Radiobioassay Intercomparison Program for Evaluation of Draft ANSI Standard N13.30 Performance Criteria for Radiobioassay," PNL-SA-10655. 29th Annual Meeting of the Health Physics Society, New Orleans, Louisiana, June 3-7, 1984.

Selby, J. M., "Criteria for Assessment and Recording Worker Doses Using ICRP-26 Recommendations as a Base," PNL-SA-12060. 29th Annual Meeting of the Health Physics Society, New Orleans, Louisiana, June 3-7, 1984.

Selby, J. M., "Draft American National Standard M42.17." Nationa T Bureau of Standards Workshop on Radiation Survey Instruments and Calibrations, Gaithersburg, Maryland, July 10-12, 1984.

Simons, G. G. "Thin TLD's for Beta Dose Measurements." 29th Annual Meeting of the Health Physics Society, New Drleans, Louisiana, June 3-7, 1984.

Stoetze1, G. A., J. L. Kenoyer, K. L. Swinth, K. R. Mashburn, "Evaluation of the Performance of Alpha Survey Instrumentation Against Requirements in a Draft Performance Standard," PNL-SA-11943. 29th Annua? Meeting of the Health Physics Society, New Orleans, Louisiana, June 3-7, 1984.

Swinth, K. L., "Assessment of the Beta Dosimetry Problem and Status of Present Programs." Interagency Committee on 0ccupationa1 Radiation Protection Measurements, Washington, D.C., December 13, 1963.
Swinth, K. L., "The DOE Contractor Perspective." National Bureau of Standards Worksmop on Radiation Survey Instruments and Calibrz. tions, Gajthersburg, Maryland, July 10-12, 1984 .

Swinth, K. L., and J. L. Kenoyer, "Evaluation of Oraft Standard N42.17 by Testing," PNL-SA-12011. Nationa I Bureau of Standards Workshop on Padiation Survey Instruments and Calibrations, Gaithersburg, Maryland, July $10-12,1984$

Swinth, K. L., and J. L. Kenoyer, "Evaluaticn of a Draft Standard on Performance Specifications for Hea? th Physics Instrumentation," PNL-SA-11625. Invited paper at the Second DOE Workshop on Portable Instrumentation and Dcsimeters in Knoxville, Tennessee, April 9-11, 1984.

Swinth, K. L, J. L. Kenoyer, K. R. Mashburn, J. M. Selby, "Evaluation of a Draft Standard on Performance Specifications for Health Physics Instrumentation - Radiological Performance," PNL-SA-12611. 29th Annual Meeting of the Health Physics Society, New Orleans. Louisiana, June $3-7,1984$.

Swinth, K. L, J. L. Kenoyer, K. R. Mashburn, J. M. Selby, "Evaluation of a Draft Standaril on Performance Specifications for Health Phys;ics Instrumentation - Radiological Performance," Spring Conference of the American Society for Nondestructive Testing in Denver, May 21-24, 1984

Swinth, K. L, P. J. McGoey, and K. K. Rhoads, "The Role of Non-Uniform Distributions in Determination of Lung Depositions of Transuranics," PNL-SA-11000. IRPA Meeting in West Bertin, May 7-12, 1984.

Tomeraasen, P. L., D. L. Haggard, M. A. Parkhurst, D. E. Hadlock, "Personnel Neutror Dosimetry l'sing Track Etch Techniques," PNL-SA-11953. 29th Arnual Meeting of the Health Physics Society, New Orleans, Louisiana, June $3-7,1984$.

Traub, R. J., B. L. Murphy, J. M. Selby, E. J. VaTTario, "Characterization of Interna] Dosimetry Practices at DOE Facilities," PNL-SA-11952. 29th Annua 7 Meeting of the Health Physics Society, New Orleans, Louisiana, June $3-7,1984$. 
Author Index 



\section{AUTHOR INDEX}

Adams, R. C.; 29, 30

Bair, W. J.; 33

Berkowitz, C.; 1

Brackenbush, L. W.; 17

Corley, J. P.; 12, 29, 30

Cross, F. T.; 27

Denham. D. H.; 27

Ecker, R. M.; 32

Endres, G. W. R.; 17, 19

Faust, L. G.; 17

Fisher, D. R.; 8

Fox, R. A.; 21

Hadley, R. T.; 8

Hadlock, D.E.; 17

Haggard, D. 1.; 17

Hawley, K. A.; 29, 30, 31

Heid, K. R.; 11, 12

Higby, D. P.; 11

Hooker, C. D.; 21
Imhoff, K. L.; 29, 30

Jaquish, R. E.; 29

Kathren, R. L.; 11

Kennedy, W. E., Jr.; 27, 29, 30

Kenoyer, J. L.; 7, 11

Kinnison, R. R.; 29

MacLellan, 1. A.; 10, 12, 13

Marks, S.; 27, 28

McDonald, J.C.; 15, 17

Mckown, G. L.; 31

Meuser, J. M.; 31

Moore, E. B., Jr.; 29, 30

Munson, L. H.; 11

Murphy, B. L.; 10, 11, 12

13, 21

Myers, D. A.; 31

Napier, B. A.; 31

Parkhurst, M. A.; 17

Peterson, S. R.; 31

Pisarcik, J. M.; 10
Ramsdell, J. V.; 31

Rathbun, L. A.; 19

Raymond, I. R.; 29, 30

Roberson, P. L.; 13, 15, 19, 21

Robinson, A. V.; 8, 10, 11

Schalla, R.; 31

Scherpelz, R. I.; 17

Selby, I. M.; 10, 12

Soldat, J. K.; 27, 28, 29

Steelman, B. L.; 31, 32

Stenner, R. D.; 27

Strenge, D. L.; 31

Swinth, K. L.; 7, 10, 15, 19

Traub, R. J.; 11, 13

VanVoris, P.; 31

Watson, E. C.; 29

Whelan, G.; 31 

Organization Charts Distribution 



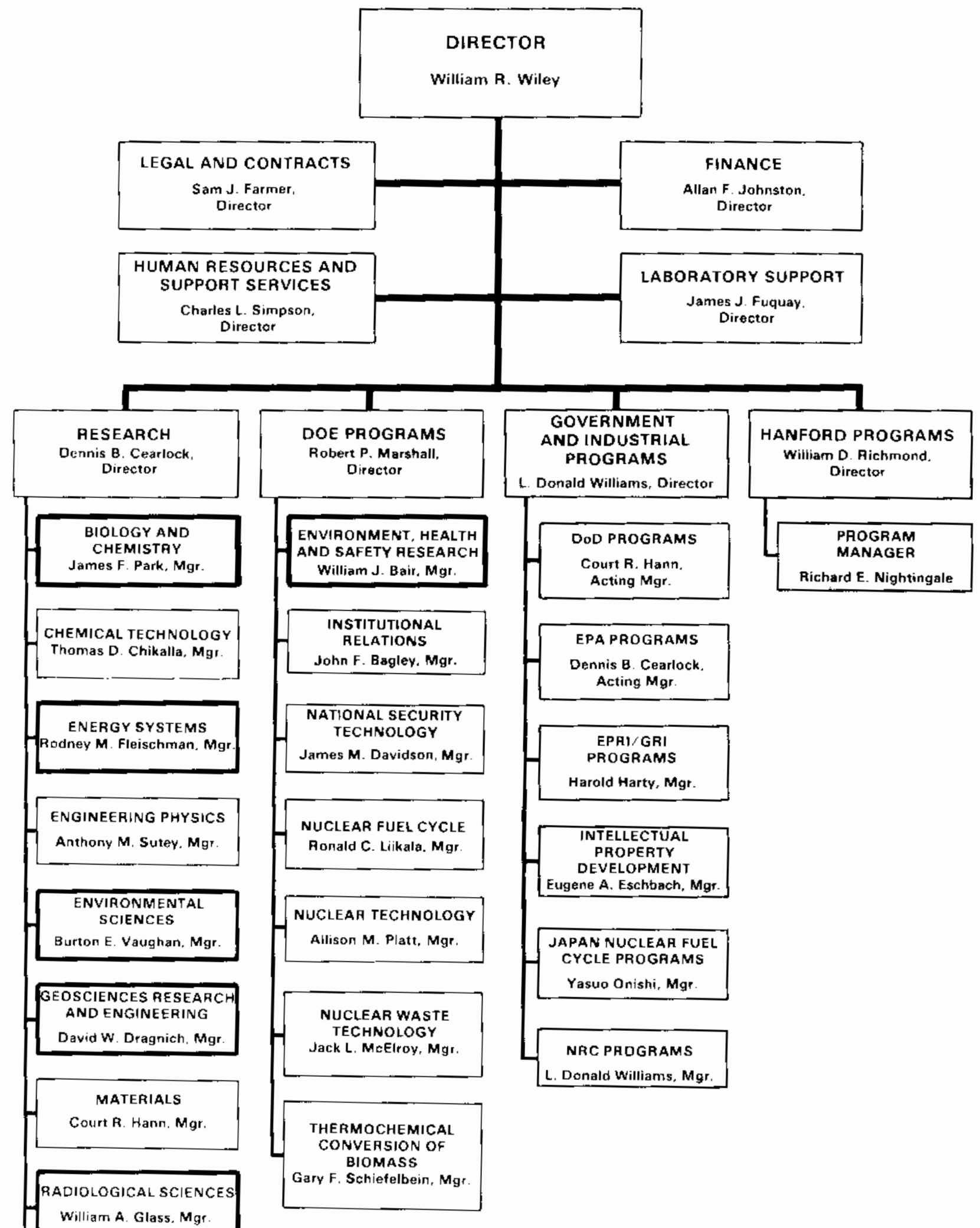

BOLD LINES DENOTE ORGANIZATIONAL COMPONENTS IN WHICH ENVIRONMENT, HEALTH AND SAFETY RESEARCH IS BEING CONDUCTED AS OF DECEMBER 1. 1984 
ENVIRONMENT, HEALTH AND SAFETY RESEARCH

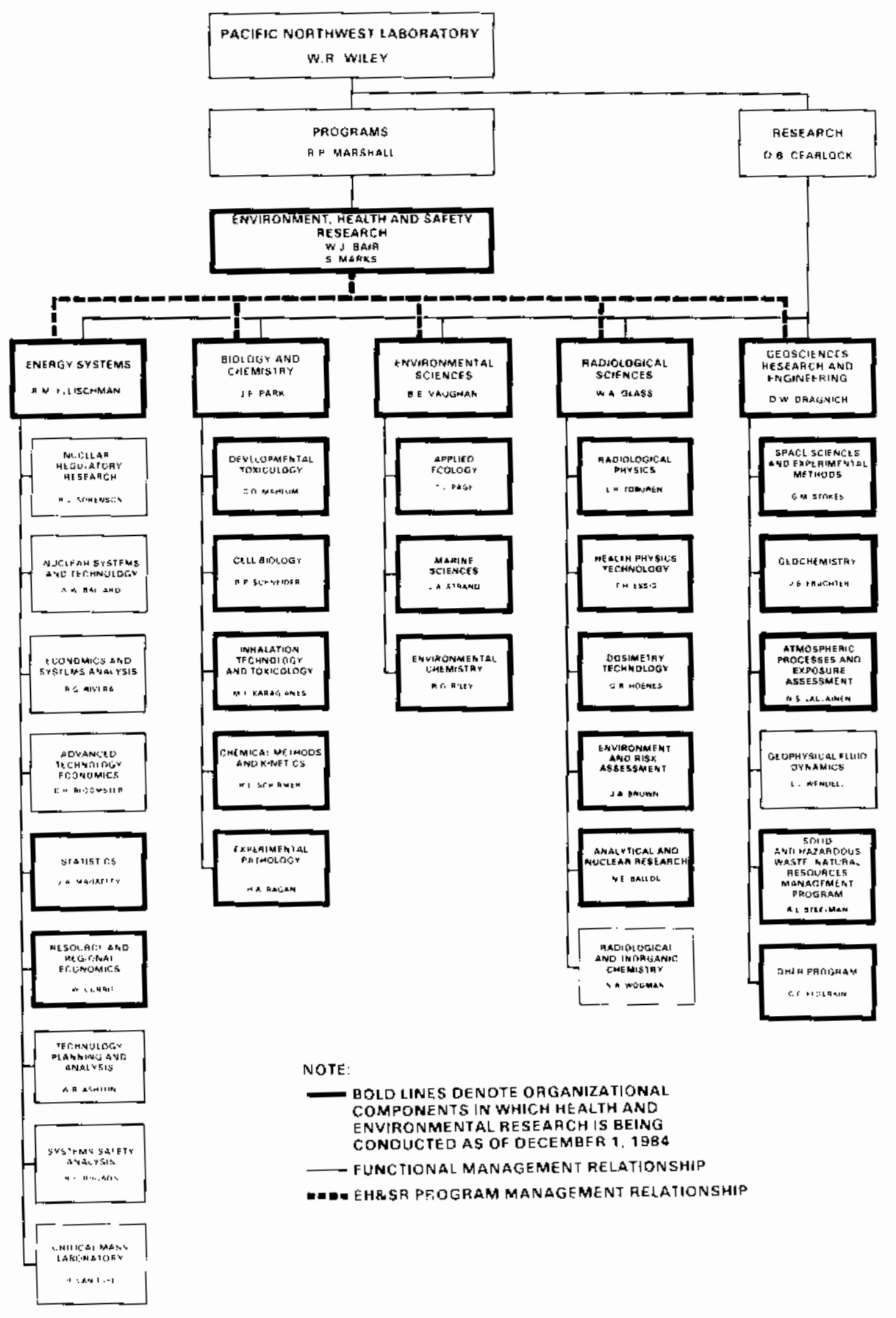


No. of

Copies

OFFSITE

W. R. Albers
FE-43, GTN
Department of Energy
Washington, DC 20545
D. Ballantine
ER-74, GTN
Department of Energy
Washington, DC 20545
R. W. Barber
PE-221, GTN
Department of Energy
Washington, DC 20545
N. F. Barr
ER-73, GTN
Department of Energy
Washington, DC 20545
J. R, Beal
ER-72, GTN
Department of Energy
Washington, DC 20545

R. P. Blaunstein

$P E-222$, GTN

Department of Energy

Washington, DC 20545

L. C. Brazely, Jr.

NE-24, GTN

Department. of Energy

Washingtor, DC 20545

P. Buhl

FE-34, GTN

Department of Energy

Washington, DC 20545

P. Cho

ER-73, GTN

Department of Energy

Washington, DC 20545

D. W. Cole, Jr.

ER-73, GTN

Department of Energy

Washington, DC 20545

R. H. Davies

PE-20, FORS

Department of Energy

Washington, DC 20585

L. J. Dea.l

PE-222, GTN

Department of Energy

Washington, DC 20545
No. of

Copies

J. Dorigan

ER-75, GTN

Department of Energy

Washington, DC 20545

G. D. Duda

ER-72, GTN

Department of Energy

Washington, DC 20545

A. P. Duhamel

ER-74, GTN

Department of Energy

Washington, DC 20545

C. W. Edington

ER-70, GTN

Department of Energy

washington, DC 20545

J. E. Fitzgerald, Jr. Department of Energy

MA-252.1, GTN

Washington, DC 20545

W. 0. Forster

ER-75, GTN

Department of Energy

Washington, DC 2.0545

T. G. Frangos

Department of Energy

PE-243, GIN

Washington, DC 20545

R. Goidsmith

ER-73, GTN

Department of Energy

Washington, DC 20545

G. Goldstein

ER-74, GTN

Department of Energy

Washington, DC 20545

D. H. Hamilton, Jr.

ER-75, GTN

Department of Energy

washington, DC 20545

H. Hollister

Department of Energy

$P E-20$, FORS

Washington, DC 20585

G. Y. Jordy

ER-30, GTN

Department of Energy

Washington, DC 20545

J. S. Kane

ER-2, FORS

Department of Energy

Washington, DC 20585
No. of

Copies

J. Kaufmann

ER-31, GTN

Department of Energy

Washington, DC 20545

I. R. Linger

ER-63, GTN

Department of Energy

Washington, DC 20545

J. N. Maddox

ER-73, GTN

Department of Energy

Washington, DC 20545

J. R. Maher

Department of Energy

PE-22, GTN

Washington, DC 20545

C. R. Mandelbaum

ER-32, GTN

Department of Energy

Washington, DC 20545

S. P. Mathur

Department of Energy

PE-245, GTN

Washington, DC 20545

D. D. Mayhew

ER-63, GTN

Department of Energy

Washington, DC 20545

H. M. McCammon

ER-75, GTN

Department of Energy

Washington, DC 20545

T. F. McCraw

Department of Energy

PE-222, GTN

Washington, DC 20545

M. L. Minthorn, Jr.

ER-72, GTN

Department of Energy

Washington, oC 20545

D. R. Monti

PE-23, GTN

Department of Energy

Washington, DC 20545

D. 0. Moses

PE-262, GTN

Department of Energy

Washington, DC 20545

H. Moses

ER-74, GTN

Department of Energy

Washington, DC 20545 
No. of

Copies

W. E. Mott

Department of Energy

PE-24, GTN

Washington, DC 20545

H. S. Osburn, Jr.

ER-75, GTN

Department of Energy

washington, DC 20545

C. L. Osterberg

ER-75, GTN

Department of Energy

Washington, DC 20545

D. E. Patterson

PE-34, GTN

Department of Energy

Washingtar, DC 20545

R. G. Rader

PE-24, GTN

Department of Energy

Washington, DC 20545

J. S. Robertson

ER-73, GTN

Department of Energy

washington, DC 20545

S. L. Rose

ER-73, GTN

Department of Energy

Washington, DC 20545

D. M. Ros 5

PE-241, GTN

Department of Energy

Washington, DC 20545

G. U. Rotariu

PE-222, GTN

Department of Energy

Washington, DC 20545

M. Schulman

ER-70, GTN

Department of Energy

Washington, DC 20545

D. H. Slade

ER-74, GTN

Department of Energy

Washington, DC 20545

D. A. Smith

ER-72, GTN

Department of Energy

Washington, DC 20545

J. Snow

Department of Energy

ER-6, FORS

Washington, DC 20585
No. of

Copies

G. E. Stapleton

ER-72, GTN

Department of Energy

Washingtom, DC 20545

R. J. Stern

PE-25, FORS

Department of Energy

Washington, DC 20585

J. Swinebroad

PE-24, GTN

Department of Energy

Washington, DC 20545

J. W. Thjessen

ER-71, GTN

Department of Energy

washington, DC 20545

A. Trivelpiece

ER-1, FORS

Department of Energy

Washington, DC 20585

E. J. Vallario

PE-222, GTN

Department of Energy

Washington, DC 20545

W. A. Vaughan

FE-1, FORS

Department of Energy

Washington, DC 20585

R. L. Watters

ER-75, GTN

Department of Energy

Washington, DC 20545

C. G. Welty, Jr.

$P E-243$. GTN

Department of Energy

Washington, DC 20545

E. R. HilTians

PE-25, FORS

Department of Energy

Washington, DC 20585

F. E. Witmer

PE-221, GTN

Department of Energy

washington, DC 20545

F. Wobber

ER-75, GTN

Department of Energy

Washington, DC 20545

R. W. Wood

ER-74, GTN

Department of Energy

Washington, DC 20545
No. of

Copies

E. W. Bean

Rocky Flats Area office

DOE - Albuquerque

Operations office

P0 Box 928

Golden, C0 80401

W. Bibb

DOE - Oak Ridge Operations Office

PO Box E

Oak Ridge, TN 37830

W. W. Burr

Oak Ridge Associated

Universities

PO Box 117

Oak Ridge, TN 37830

G. P. Dix

26619 Haney Avenue

Damascus, MD 20750

D. M. Gardiner

DOE - Chicago Operations Office

9800 South Cass Avenue

Argonne, IL 60439

D. S. Ingle

Dayton Area Office

DOE - Albuqueruqe

Operations office

PO Box 66

Miamisburg, OH 45342

R. Nelson

DOE - Nevada Operations office

P0 Box 14100

Las Vegas, NV 89114

R. Ray

DOE - Nevada Operations Office

PO Box 14100

Las Vegas, NV 89114

J. R. Roeder

DOE - ATbuquerque

Operations office

PO Box 5400

Albuquerque, NM 87115

J. H. Spickard

DOE - Idaho Operations

Commission

550 Second Street

Idaho Falls, ID 83401

M. M. Williamson

DOE - Idaho Operations

Commission

550 Second Street

Idaho Falls, ID 83401 
No. of

Copies
No. of

Copies

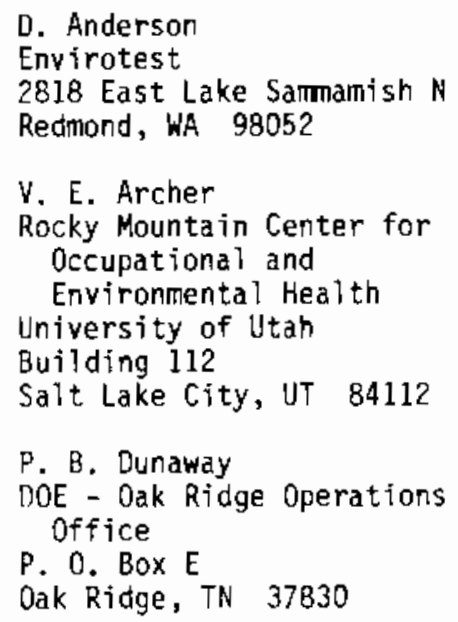

R. Alexander

Nuciear Regulatory

Commission

Washington, DC 20555

W. Cool

Nuclear Regulatory Commission

washington, DC 20555

J. Cunninghan

Nuclear Regulatory Commission

Washington, DC 20555

N. A, Derinis

Nuclear Regulatory

Commission

Wastington, DC 20555

B. K. Grimes

Nuclear Regulatory Commission

Washington, DC 2D555

P. F. Hayes

Nuclear Regulatory Commission

Wahington, DC 20555

M. W. Jankowski

Nuclear Regulatory Commission

Washington, DC 20555

W. Mills

Nuclear Regulatory Commission

Washington, DC 20555

5. M. Neuder

Nuclear Regulatory

Comission

Washington, DC 20555

NRC Advisory Committee on Reactor Safeguards

Washington, DC 20555

R. A. Scarano

Nuciear Regulatory Commission

Washington, DC 20555

D. E. Solberg

Nuclear Regulatory Commission

Washington, DC 20555

K. G. Steyer

Nuciear Regulatory Commission

Washington, DC 20555
No. of

Copies

\author{
V. P. Bond \\ Brookhaven National \\ Laboratory \\ Upton, Long Island \\ NY 11973 \\ G. Burley \\ Environmental Protection \\ Agency \\ Washington, DC 20460 \\ H. Drucker \\ Argonne National \\ Laboratory \\ 9700 South Cass Avenue \\ Argonne, IL 60439 \\ H. H. Ellett \\ Environmental Protection \\ Agency \\ Washington, DC 20460 \\ Librarian \\ Research Library, \\ Reference \\ Brookhaven National \\ Laboratory \\ Upton, Long Island \\ NY 11973
}

N. Nelson

Environmental Protection Agency

Washington, DC 20460

W. R. Ney

Executive Director

National Council on Radiation Protection and Measurements

7910 Woodmont Avenue

Suite 1016

Washington, DC 20014

A. Richardson

Environmental Protection Agency

Washington, DC 20460

w. Sinclair

National Council on Radiation Protection and Measurements

7910 Woodmont Avenue

Suite 1016

Washington, DC 20014

F. Swanberg

Nuclear Regulatory

Commission

Washington, DC 20555 
No. of

Copies

H. L. Volchok

Department of Energy

Environmental Measurements Laboratory

376 Hudson St.

New York, NY 10014

E. L. ATpen

Director, Donner Laboratory

University of Califormia

Building 90, Room 2056

No. 1 Cyclotron Raad

Berkeley, CA 94720

27 DOE Technical Information Center

R. $\mathrm{Hall}$

Savannah River Laboratory

E. I. duPont de Nemours

and Company

Aiken, SC 29801

R. M. Jefferson

Sandia Laboratories

PO Box 5800

Albuquerque, NM 87187

Librarian

Lawrence Radiation

Laboratory

University of California Technical Information Department, L-3

PO Box 808

Livermore, CA 94500

C. B. Meintold

Brookhaven National Laboratory

Upton, Long Isiand

NY 11973

M. L. Mende 1 sohn

Univerasity of California

Lawrence livermore National Laboratory PO Box 808

Livertmore, CA 94550

C. R. Richmond

Oak Ridge National Laboratory

PO Box $X$

Dak Ridge, TN 37830

Y. E. Ricker

Lawrence Livermore

National Labortory

PO Box 5507

Livermore, CA 94550
No. of

Copies

k. A. Smith

Sandia Labortories

PO Box 5800

Albuquerque, NM 87187

Technical Information Service

Room 773A

Savannah River Laboratory

E. I. duPont de Nemours and Company

Aiken, SC 29801

J. H. Birely

Los Alamos Nationa?

Laboratory

University of California

PO Box 1663

Los Alamos, NH 87545

R. Catlin

Electric Power Research Institute

3412 Hillview Avenue

Palo Alto, CA 94304

J. W. Healy

Los Alamos National

Laboratory

University of California

PO Box 1663

Los Alamos, NM 87545

J. 0. Jackson

Los Alamos Nationa?

Laboratory

University of California

PO Box 1663

Los ATamos, NM 87545

R. Lunt.

University of Caifornia

Center of Life Sciences

900 Veteran Avenue

West Los Angeles, CA 90024

R. 0. McClellan

Inhalation Toxicology

Research Institute

Lovelace Foundation for

Medical Education and

Research

P0 Box 5890

Albuqueruge, NM 87185

A. H. Adelman

Battelle Columbus

Laboratories

$505 \mathrm{King}$ Avenue

Columbus, Ohio 43201
No. of

Copies

A. D. Barker

Battelle Columbus

Laboratories

505 King Avenue

Columbus, Ohio 43201

D. N. Gideon

Battelle Columbus

Laboratories

505 King Avenue

Columbus, Orio 43201

F. J. Milford

Battelle Columbus

Laboratories

$505 \mathrm{King}$ Avenue

Columbus, Ohio 43201

N. E. Carter

Battelle Columbus

Laboratories

505 Xing Avenue

Columbus, Ohio 43201

L. L. German

Battelle Columbus

Laboratories

$505 \mathrm{King}$ Avenue

Columbus, Ohio 43201

R. S. Paul

Battelle Columbus

Laboratories

505 King Avenue

Columbus, Ohio

43201

D. B. Shipler

Battelle Columbus

Laboratories

505 King Avenue

Columbus, Ohio

43201

L. R. Vest

Battelle Memorial

Institute

Washington Operations

Washington, DC 20036

G. B. Johnson

Battelle Menorial

Institute

Washington Operations

Hashington, DC 20036

5. H. Stryker

Batte?le Memoria Institute

Washington Operations

Washington, DC 20036

D. W. Moelier

Harvard School of Public Health

Harvard University

Cambrdige, MA 02138 
No. of

Copies

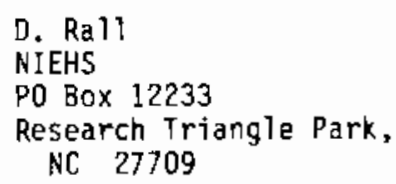

G. L. Voelz

Los Alamos National

Laboratory

po Box 1663

Los Alamos, AM 87545

W. Weyzen

Electric Power Research Institute

3412 Hillview Avenue

$\mathrm{Pa}$ lo Alto, CA 94304

D. Bierman

Chief, Document Service Branch

Central Intelligence Agency

Attn: CRS/DPSD/DSB/IAS/ 409779/08

Washington, DC 20505

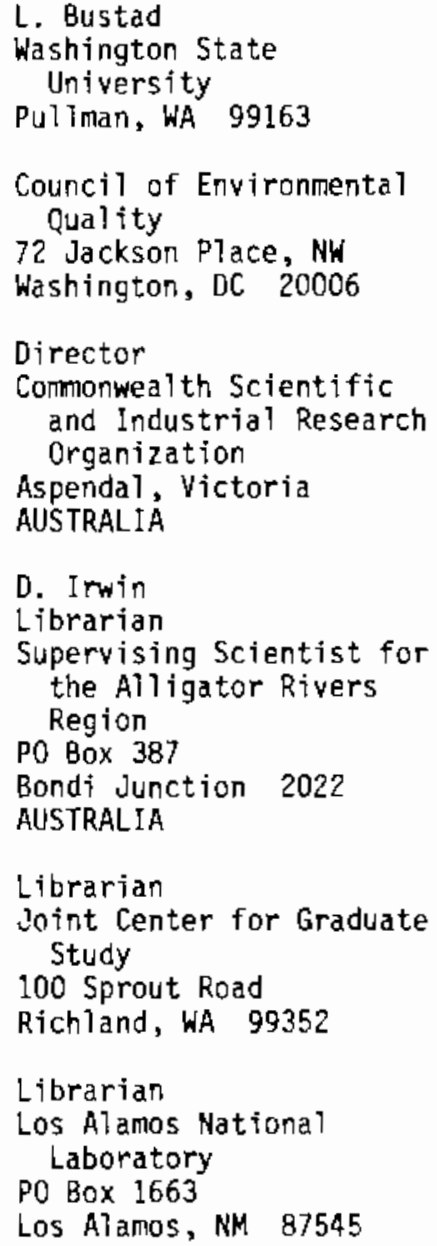

L. Bustad

Washington State University

Puliman, WA 99163

Council of Environmental Qual ity

72 Jackson Place, NW

Washington, DC 20006

Director

Commonwealth Scientific and Industrial Research Organization

Aspendal, Victoria

AUSTRALIA

D. Irwin

Librarian

Supervising Scientist for the Alligator Rivers

Region

PO Box 387

Bondi Junction 2022

AUSTRALIA

Librarian

Joint Center for Graduate Study

100 Sprout Road

Richland, WA 99352

Librarian

Los Alamos National

Laboratory

PO Box 1663

Los Alamos, NM 87545

No. of

Copies

J. W. McCasiin

INEL, Aerojet Nuclear

550 Second Street

Idaho Fal1s, ID 83401

M. E. Wrenn

University of Utah

Building 351

Salt Lake City, UT 84112

R. E. Yoder

Rockwell Internationa

PO Box 464

Golden, CO 80401

M. Anderson

Library

Department of National Health and Welfare

Ottowa, Ontario

CANADA

G. Cowper

Atomic Energy of Canada. Limited

Chalk River Nuclear Laboratories

Chaik River, Ontario

KOJ IJO

CANADA

H. Daw

Director, Division of Health, Safety and Waste Management

International Atomic Energy Agency

Vienna I, Kaerntnerring II

AUSTRIA

$$
\begin{aligned}
& \text { Wu De-Chang } \\
& \text { Institute of Radiation } \\
& \text { Medicine } \\
& \text { 11\# Tai Ping Road } \\
& \text { Beijing } \\
& \text { THE PEOPLE'S REPUBLIC } \\
& \text { OF CHINA }
\end{aligned}
$$

\section{G. B. Gerber}

Radiobiology Department

Commission of European Communities

Rue de la l.o'

Brussels

BLEGIUM

Librarian

Australian AEC

Riverina Laboratory

P0 $80 \times 226$

Deniliquin

New South Wales

AUSTRALIA 2710
No. of

Copies

\author{
Librarian \\ Commonwealth Scientific \\ and Industrial Research \\ Organization \\ 314 Albert Street \\ P0 Box 89 \\ East Melbourne, Victoria \\ AUSTRALIA
}
A. M. Marko
Director, Atomic Energy of Canada Ltd.
Biology and Health Physics Division
Chalk River Nuclear Laboratories
Chalk River, Ontario
KOJ IJO
CANADA
Li De-ping
Professor and Director of North China Institute of Radiation Protection, MNI
P. 0. Box 120
Tai-yuan, Shan-xi
THE PEOPLE'S REPUBLIC OF CHINA

\section{Wang Hengde}

North China Institute of Radiation Protection

PO Box 120

Taiyuan City, Shanxi Province

THE PEOPLE'S REPUBLIC OF CHINA

Shu-Zheng Liu, M.D. Department of Radiation Biology

Bethune Medical University

7 Xinmin Street

Changchun, Jil in

THE PEOPLE'S REPUBLIC OF

CHINA

Wang Ruifa

Associate Director

Laboratory of Industrial Hygiene

Ministry of Public Health

2 Xinkang Street

Deshangmanwai, Beijing

THE PEOPLE'S REPUBLIC OF CHINA

Sun Shi-Quan

Head of Radiation-Medicine Department

North China Institute of Radiation Protection

Taj-yuan, Shanaxi

THE PEOPLE'S REPUBLIC OF CHINA 
No. of

Copies

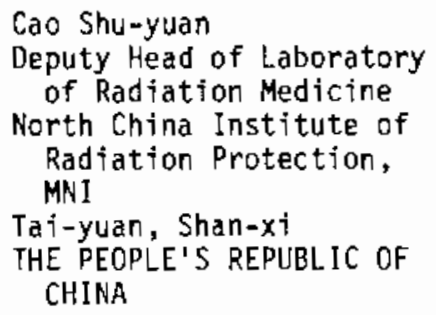
of Radiation Medicine

North China Institute of Radiation Protection, MNI

Tai-yuan, Shan-xi

THE PEOPLE'S REPUBLIC OF CHINA

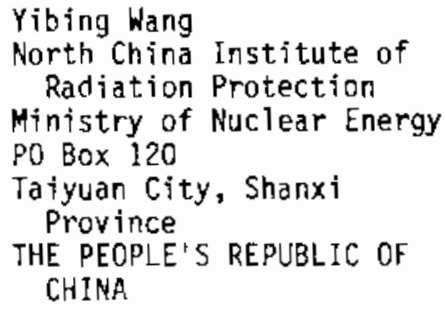

Chen Xing-an

Laboratory of Industrial Hygiene

Ministry of Public Health

2 Xinkang Street

Deshengmenwai, Beijing

THE PEOPLE'S REPUBLIC OF CHINA

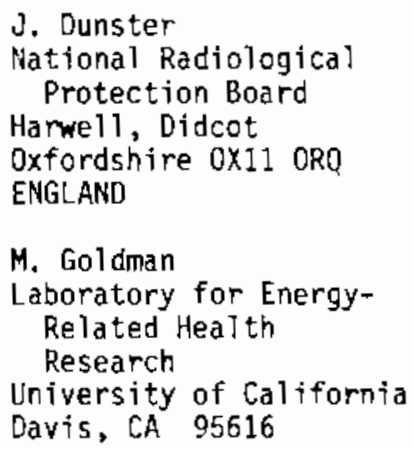

No. of

Copies

Wei Luxin

Laboratory of Industrial Hygiene

Ministry of Public Health

2 Xinkang Street

Deshengmenwai, Beijing

THE PEOPLE'S REPUBLIC OF

CHINA

H. Smith

Head of Biology Department

Health of Biology Department

National Radiological Protection Board

Chilton, Didcot

Oxon OX11 ORO

ENGLAND

Deng Zhicheng

North China Institute of Radiation Protection

Taiyuan, Shanxi Province

THE PEOPLE'S REPUBLIC OF CHINA

Zhu Zhixian

Laboratory for EnergyRelated Health Research

University of California

Davis, CA 95616

A. M. Beau (Librarian)

Commissariat al'Energie Atomique

Fontenay Aux Roses

FRANCE

Director

Commissariat a l'Energie Atomique

Centre d'Etudes

Nucleaires de Fontenayaux Roses

FRANCE

M. Fitoussi

Comissariat a l'Energie Atomique

Department de Protection

B.P. 6

F-92260 Fontenay aux Roses

FRANCE

Librarian

Centre d'Etudes

Nucleaires de Saclay

Po Box 2, Saclay

Fig-sur-Yvette (S D)

FRANCE
No, of

Copies

\author{
Librarian \\ ENEA (OECD) Health and \\ Safety office \\ 38, Blvd. Suchet. \\ Paris, \\ FRANCE \\ J. C. Nenot \\ Comissariat a ?'Energie \\ Atomique/SPS \\ BP 6/F92260 \\ Fontenay-aux-Roses \\ FRANCE
}

J. P. 01iver

ENEA (OECD) Health and Safety office

38 , B1vd. Suchet

Paris,

FRANCE

M. Rzekiecki

Commissariat a I'Energie Atomique

Centre d'Etudes

Nucleaires de Cadarache

BP n 13-St. Pau?

Les Durance

FRANCE

F. D. Sowby

Intermationa 1 Commission on Radiological

Protection

CTifton Avenue

Sutton, Surrey

ENGLAND

J. Booz

KFA Julich, Institute of Medicine

D-5170 JuTich 1

Postfach 1913

FEDERAL REPUBLIC OF WEST GERMANY

L. Feinendegen

Director of Institute of Medicine

Institut fur Medizin

Kernforchung sanlage Julich

Postfach 1913

517, Julich

FEDERAL REPUBLIC OF WEST GERMANY

A. R. Gopal-Ayengar C/o Mr. P. K. Dayanidhi 15-0 Gulmarg, Amushaktinagar Bombay-400 094 INDIA 
No. of

Copies
W. Jacobi
Institut fur
Strahlenschutz
D-8042 Neuherberg
Ingoistraddter
Landstrasse 1
FEDERAL REPUBLIC OF
WEST GERMANY

\section{H. J. Klimisch \\ BASF Aktiengesellschaft Abteilung Toxikologie \\ 6700 Ludwigshafen \\ FEDERAL REPUBLIC OF \\ WEST GERMANY}

\section{T. Kumatori \\ Director \\ National Institute of \\ Radiological Sciences \\ 4-9-1, Anagawa \\ Chiba-shi, Chiba 260 \\ JAPAN}

\section{H. G. Paretzke \\ GSF \\ D-8042 Neuherberg \\ FEDERAL REPUBLIC OF WEST GERMANY}

V. Prodi

Department of Physics

University of Bologna

Via Irmerio 46

I-40126 Bologna

ITALY

Professor Rotondi

CNEN CSN Cassacia

Caseila Postale 2400

1-0100 Roma

ITALY

J. K. Basson

Vice-President

Raad Op Atomic

Atoomkrag Energy Board

Privaatsk $\times 256$

Pretoria 0001

REPUBLIC OF SOUTH AFRICA

Z. M. Beekman

President of IRPA

Rooseveltlaan 197

1079 AP Ansterdam

THE NETHERLANOS

A. Brink

Sasol-0ne Limited

PO Box 1

Sasolburg 9570

REPUBLIC OF SOURTH AFRICA
No. of

Copies
D. Djuric
Institute of Occupational
Radiological Health
11000 Beograd
DeTigradska 29
YUGOSLAVIA

K. E. Lennart Johansson National Defense Research Institute

FOA 451

S-901-82

Unrea

SWEDEN

E. Komarov

Environmental Health

Division

World Health Organization

Avenue Appia 1211

Geneva 27

SWITZERLAND

M. J. Suess

Regional officer for Environmental hazards

World Health Organization

8, Scherfigsvej

DK-2100

Copenhagen

DENMARK

B. C. Winkler

Director, Licensing (Standards)

Raad Op Atoomkrag/Atomic Energy Board

Privaatsak $\times 256$

Pretoria 0001

REPUBLIC OF SOUTH AFRICA

Denq Zhicheng

North China Institute of Radiation Protection

Taiyuan, Shanxi Province

THE PEOPLE'S REPUBLIC OF CHINA

\section{Zhu Zhixian \\ Laboratory for Energy- Related Heal th Research \\ University of California \\ Davis, CA 95616}

Xie Zi

Senior Engineer

Scientific Secretary of Radiation Protection Laboratory

Institute of Atomic Energy

P0 Box 275, Biejing

THE PEOPLE'S REPUBLIC OF CHINA
No. of

Copies

Pan Zi-qiang

Head of Health Physics Laboratory

Atomic Energy Institute

Beijing

THE PEOPLE'S REPUBLIC OF CHINA

ONSITE

3 OOE Richland Operations Office

H. E. Ransom/P. K. Clark/ E. L. Nilson

D. R. Elle

J. L. Rhoades

Rockwell Hanford Operations

P. G. Lorenzini

2 Westinghouse Hanford Company

R. 0. Budd

D. E. Simpson

2 Hanford Environmental health Foundation

B. D. Breitenstein

R. 0. Gilmore

UNC Nuclear Industries

M. A. Payne

9 Battelle-Seattle

F. A. Morris

S. M. Nealey

E. B. Perrin

W. L. Rankin

A. H. Schilling

C. R. Schuller

R. Shikiar

M. E. Walsh

M. T. Wood

130 Pacific Northwest Laboratory

R. C. Adams

R. W. Baalman (10)

W. J. Bair (20)

E. G. Baker

C. M. Berkowitz

J. C. Bower

L. W. Brackenbush

T. D. Chikalla

J. P. Corley

F. T. Cross 
No. of

Copies

Pacific Northwest Laboratory (contd)

J. M. Davidson

D. E. Deonigi

D. H. Denham

R. M. Ecker

C. E. Elderkin

G. W. R. Endres

S. J. Farmer

L. G. Faust

D. R. Fisher

J. J. Fix

R. A. Fox

U. J. Fuquay

W. A. Glass (5)

R. H. Gray

R. T. Hadley

D. E. Hadlock

D. L. Haggard

C. R. Hann

K. A. Hawley

K. R. Heid

D. P. Higby

C. D. Hooker

K. L. Imhoff

R. E. Jaquish

R. L. Kathren

W. E. Kennedy, Jr.

J. L. Kenoyer

R. R. Kinnison
No. of

Copies

Pacific Northwest Laboraotry (contd)

H. V. Larson

R. C. Li ikala

J. A. MacLellan

5. Marks

G. D. Marr

R. P. Marshall

J. C. McDonald

G. L. Mckown

J. E. Mendel

J. M. Meuser

J. E. Minor

E. B. Moore, dr.

L. H. Munson

B. L. Murphy

D. W. Murphy

I. C. Nelson

D. A. Myers

B. A. Napier

K. 0 . Nelson

J. M. Nielsen

R. E. Night ingale

M. A. Parkhurst

S. R. Peterson

J. M. Pisarcik

A. M. Platt

J. V. Ramsde1?

L. A. Rathbun

J. R. Raymond
No. of

Copies

\section{Pacific Northwest}

Laboratory (contd)

W. D. Richmond

J. A. Roberson

P. L. Roberson

A. V. Robinson

R. Schalla

R. I. Scherpelz

G. F. Schiefelbein

L. C. Schmid

J. B. Schuette

J. M. Selby

R. Shikiar

C. L. Simpson

J. K. Soldat

D. L. Strenge

R. D. Stenner

A. M. Sutey

K. L. Swinth

R. J. Traub

B. E. Vaughan

P. VanVoris

S. E. Vickeman

E. C. Watson

W. R. Wiley

L. D. Williams

G. Whelan

Technical Information (5)

Publishing Coordination (2:, 